\title{
Novel Phenothiazine-Bridged Porphyrin-(Hetero)aryl dyads: Synthesis, Optical Properties, In Vitro Cytotoxicity and Staining of Human Ovarian Tumor Cell Lines
}

\author{
Eva Molnar ${ }^{1}$, Emese Gal ${ }^{1}$, Luiza Gaina ${ }^{1} \mathbb{D}$, Castelia Cristea ${ }^{1, *} \mathbb{C}$, Eva Fischer-Fodor ${ }^{2,3}$, \\ Maria Perde-Schrepler ${ }^{2}\left(\mathbb{D}\right.$, Patriciu Achimas-Cadariu $\left.{ }^{4,5}{ }^{(}\right)$, Monica Focsan ${ }^{6}(\mathbb{C}$ \\ and Luminita Silaghi-Dumitrescu ${ }^{1}$ (1)
}

1 The Research Center on Fundamental and Applied Heterochemistry, Department of Chemistry, Faculty of Chemistry and Chemical Engineering, Babeş-Bolyai University, 11 Arany Janos street, RO-400028 Cluj-Napoca, Romania; molnar_evike@yahoo.com (E.M.); emese@chem.ubbcluj.ro (E.G.); gluiza@chem.ubbcluj.ro (L.G.); lusi@chem.ubbcluj.ro (L.S.-D.)

2 Department of Radiobiology and Tumor Biology, Institute of Oncology "Prof.Dr. Ion Chiricuta", 34-36 Republicii street, RO-400015 Cluj-Napoca, Romania; efischerfodor@yahoo.com (E.F.-F.); pmariaida@yahoo.com (M.P.-S.)

3 Medfuture Research Center for Advanced Medicine, University of Medicine and Pharmacy Iuliu Hatieganu, 8 Babes street, RO-400012 Cluj-Napoca, Romania

4 Department of Surgery, Institute of Oncology "Prof.Dr. Ion Chiricuta", 34-36 Republicii street, 400015 Cluj-Napoca, Romania; patrick.achimas@hotmail.com

5 Department of Surgery and Gynecological Oncology, University of Medicine and Pharmacy Iuliu Hatieganu, 23 Marinescu street, 400337 Cluj-Napoca, Romania

6 Institute for Interdisciplinary Experimental Research in Bionanoscience, Nanobiophotonics Laboratory, Babeş-Bolyai University, 42 Laurian street, 400271 Cluj-Napoca, Romania; monica.iosin@phys.ubbcluj.ro

* Correspondence: castelia@chem.ubbcluj.ro; Tel.: +40-264-593833

Received: 26 March 2020; Accepted: 26 April 2020; Published: 30 April 2020

\begin{abstract}
We report here the synthetic procedure applied for the preparation of new $\mathrm{AB}_{3}$-type and trans- $\mathrm{A}_{2} \mathrm{~B}_{2}$ type meso-halogenophenothiazinyl-phenyl-porphyrin derivatives, their metal core complexation and their peripheral modification using Suzuki-Miyaura cross coupling reactions with various (hetero)aryl (phenothiazinyl, 7-formyl-phenothiazinyl, (9-carbazolyl)-phenyl and 4-formyl-phenyl, phenyl) boronic acid derivatives. The meso-phenothiazinyl-phenyl-porphyrin (MPP) dyes family was thus extended by a series of novel phenothiazine-bridged porphyrin-(hetero)aryl dyads characterized by UV-Vis absorption/emission properties typical to the porphyrin chromophore, slightly modulated by increasing the size of peripheral substituents. Three phenothiazine-bridged porphyrin-heteroaryl dyads with fluorescence emission above $655 \mathrm{~nm}$ were selected as fluorophores in red spectral region for applications in cellular staining of human ovarian tumors. In vitro experiments of cell metabolic activity displayed a moderate toxicity on human ovarian tumor cell lines (OVCAR-3, cisplatin-sensitive A2780 and cisplatin-resistant A2780cis respectively). Visualization of the stained living cells was performed both by fluorescence microscopy imaging and by fluorescence lifetime imaging under two photon excitation (TPE-FLIM), confirming their cellular uptake and the capability of staining the cell nucleus.
\end{abstract}

Keywords: meso-aryl-porphyrin; metal-porphyrin; phenothiazine; carbazole; UV-Vis spectroscopy; cytotoxicity; fluorescence imaging; TPE-FLIM 


\section{Introduction}

The multiple functionalization possibilities of the highly stable planar macrocyclic porphin core combined with the huge progress recorded in the development of methodologies for synthetic organic chemistry mostly concurred with the expansion of recent literature data documenting new porphyrin derivatives with tailored chemical and optical properties. Introduction of appropriate donor/acceptor substituents and/or metal complexation contributed to the modification of structural factors, such as molecular symmetry, size and degree of conjugation of the $\pi$-electronic system, emphasizing a high impact on the optical performances of the porphyrin-based materials. Among the various heteroaromatic units attached to the porphine chromophore aiming the modulation of its photophysical properties, the introduction of an electron rich phenothiazine unit gave fruitful returns; e.g., fluorescent porphyrins emitting intense red light with high fluorescent quantum yields [1] "push-pull" porphyrin dyes for photon to energy conversion systems [2-5] as well as potential biologically active compounds [6]. The syntheses, optical properties and electrochemical behaviors of meso-phenothiazinyl-phenyl porphyrin (MPP) dyes were first reported by our group [7] followed by the description of their metal complexation [8].

The Suzuki-Miyaura cross-coupling between organoboron derivatives and organic halides in the presence of a palladium catalyst and a base became a powerful methodology for carbon-carbon bond formation [9]. This palladium-mediated cross-coupling reaction heavily benefits from the availability of: organoboron reagents (which are inert to water and oxygen, and characterized by thermal stability and low toxicity [10]); tetra-coordinated palladium-phosphine complex catalysts, such as $\mathrm{Pd}\left(\mathrm{PPh}_{3}\right)_{4}$, $\mathrm{Pd}\left(\mathrm{PPh}_{3}\right)_{2} \mathrm{Cl}_{2}, \mathrm{Pd}(\mathrm{dppf}) \mathrm{Cl}_{2}$ or $\mathrm{Pd}_{2}(\mathrm{dba})_{3}$ [11]; and different bases, such as $\mathrm{Cs}_{2} \mathrm{CO}_{3}$ [12], $\mathrm{K}_{2} \mathrm{CO}_{3}$ [13], $\mathrm{KO} t \mathrm{Bu}$ [14], $\mathrm{K}_{3} \mathrm{PO}_{4}$ [15] or $\mathrm{NEt}_{3}$ [16].

A vast array of methodology options became accessible taking into consideration that both phenothiazine and porphyrin derivatives can be used as coupling partners in Suzuki-Miyaura cross coupling reactions either as halogeno or arylboronic derivatives. Phenothiazinylboronic acid derivatives were successfully synthesized from brominated phenothiazines either by bromine-lithium exchange followed by trapping with trialkylborate or by palladium-catalyzed borylation with tetramethyl dioxoborolane [17], while various (hetero)aryl substituents were attached to the phenothiazine core by Suzuki cross-coupling when starting with commercial chlorophenothiazine [18] or readily accessible 3,7-halogeno-phenothiazine derivatives [19-21]. The coupling of $\mathrm{A}_{2} \mathrm{~B}_{2}$-type meso-bromoporphyrin with arylboronic acid derivatives was performed under mild conditions (aqueous $\mathrm{Na}_{2} \mathrm{CO}_{3}$ as a base in DMF) [22]. Starting from meso-borylporphyrin and meso-bromoporhyrin, [23] a meso-meso-linked porphyrin system was obtained using catalytic amounts of $\mathrm{Pd}\left(\mathrm{PPh}_{3}\right)_{4}, \mathrm{Cs}_{2} \mathrm{CO}_{3}$ in $\mathrm{DMF} /$ toluene solution. A combination of $\mathrm{Cs}_{2} \mathrm{CO}_{3}$ and a $\mathrm{Pd}(0)$-complex was employed in the cross coupling of iodoferrocene and 5,15-diphenyl-10-borylporphyrin or other bulky boronic acids [24]. (e.g., polycyclic aromatic hydrocarbons [25].)

In this work, the MPP dyes family was expanded through the preparation of phenothiazine-bridged porphyrin-(hetero)aryl dyads. The described synthetic methodology is based on Suzuki-Miyaura cross coupling reaction between $\mathrm{AB}_{3}$ or trans- $\mathrm{A}_{2} \mathrm{~B}_{2}$ type meso-bromophenothiazinyl-phenyl-porphyrines (generally labeled BrMPP) with (hetero)aryl boronic acid derivatives (phenothiazinyl, substituted phenyl). Novel $\mathrm{A}_{4}$-type phenyl-bridged porphyrin-phenothiazine dyads were obtained by Suzuki-Miyaura cross coupling between meso-tetrakis(4-bromo-phenyl)porphyrin (BrTPP) and phenothiazinyl-boronic acid derivatives. The optical UV-Vis absorption/emission properties of the newly synthesized compounds were investigated in our pursuit for $\pi$-expanded porphyrins characterized by a bathochromic shift of the typical absorption/emission maxima. The effect of metal core substitution on the UV-Vis optical response of $A_{3}$ or trans $-A_{2} B_{2}$ type halogenoMPP was also examined. Aiming the distinct visualization of human ovarian tumors, three phenothiazine-bridged porphyrin-heteroaryl dyads were tested as fluorophores in red spectral region for cellular staining of human ovarian tumors; following this goal their cytotoxicity was studied by means of colorimetric assays, while their ability to stain human ovarian tumor cell lines was proved by both fluorescence 
microscopy imaging and non-invasive two photon excited-fluorescence lifetime imaging microscopy (TPE-FLIM) technique.

\section{Results}

\subsection{Synthesis of Novel MPP Dyes}

\subsubsection{Meso-(Halogenophenothiazinyl-Phenyl)Porphyrins}

Meso-Halogenophenothiazinyl-phenylporphyrin dyes (halogen-MPP) of $\mathrm{AB}_{3}$-type (halogen-MPP 2 containing one peripheral halogenophenothiazine unit) and trans- $\mathrm{A}_{2} \mathrm{~B}_{2}$ type (halogen-MPP 3 containing two peripheral halogenophenothiazine units) presented in Scheme 1 were prepared by mixed condensation of pyrrole with benzaldehyde and 7-bromo-10-methyl-phenothiazin-3-carbaldehyde 1a or 8-chloro-10-methyl-phenothiazin-3-carbaldehyde $\mathbf{1 b}$ respectively, based on our previously reported procedure, which affords MPP dyes containing a variable number of phenothiazinyl units attached to the peripheral meso positions of the central porphyrin core [7]. The presence of the halogen atom on the phenothiazine carbaldehyde substrate did not impede the outcomes of the macrocycle synthesis (yields 10-18\%) and the separation of 2 and 3 obtained in 3:2 weight ratio was done by column chromatography. The starting bromophenothiazine carbaldehyde 1a was prepared from phenothiazine substrate by successive N-methylation; Vilsmeier formylation; and finally, bromination of the phenothiazine carbaldehyde intermediate [26], while $\mathbf{1} \mathbf{b}$ was prepared starting with commercial 2-chlorophenothiazine which required protection by $\mathrm{N}$-methylation before applying the similar Vilsmeier formylation procedure.

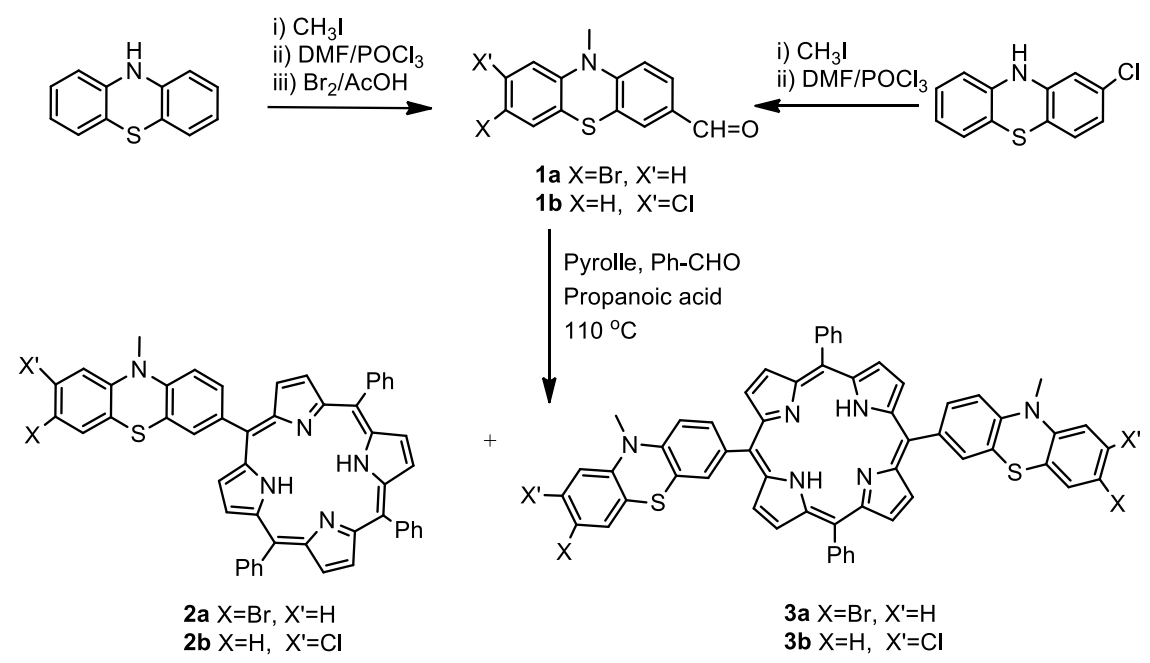

Scheme 1. Synthesis of novel halogen-MPP containing peripheral halogenophenothiazine units.

\subsubsection{Meso-(Halogenophenothiazinyl-Phenyl)Porphyrin Metal Complexes}

Metalation of halogenoMPP $\mathrm{AB}_{3}$ type $\mathbf{2} \mathbf{a}, \mathbf{b}$ and trans- $\mathrm{A}_{2} \mathrm{~B}_{2}$ type $\mathbf{3} \mathbf{a}, \mathbf{b}$ with $d$-block elements possessing polarizable valence electrons capable of perturbing the $\pi$-electron system of the porphyrin core was performed in order to underscore the effects of metal core substitution on their reactivities and UV-Vis optical properties. The complexation of the central cavity of the halogen-MPP macrocycles 2, 3 was accomplished by the treatment with the appropriate metal (II) acetate in $\mathrm{N}, \mathrm{N}$-dimethylformamide (DMF) solution [27]. In Scheme 2 are the metal-complexes obtained by incorporation of $\mathrm{Zn}(\mathrm{II}), \mathrm{Pd}(\mathrm{II})$ $\mathrm{Ni}(\mathrm{II})$ and $\mathrm{Cu}(\mathrm{II})$, metal ions respectively in halogen-MPP ligands containing one $(4,5)$ or two peripheral phenothiazine units $(6,7)$ 


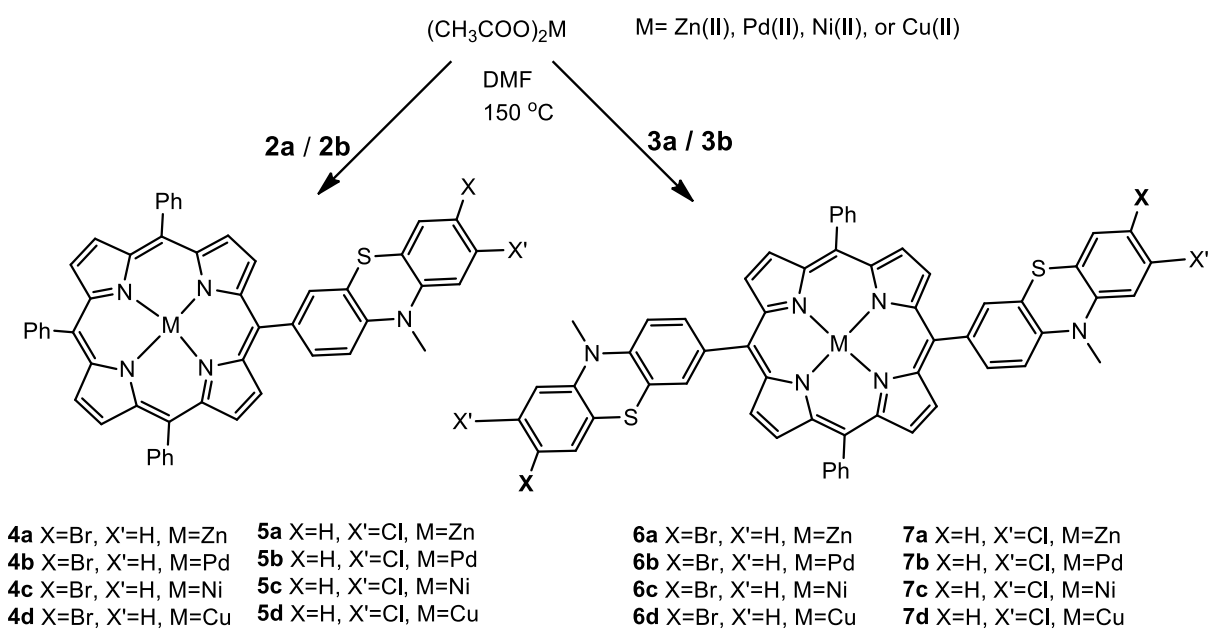

Scheme 2. Synthesis of $\mathrm{Zn}(\mathrm{II}), \mathrm{Pd}(\mathrm{II})$, Ni(II) or $\mathrm{Cu}(\mathrm{II})$ metal complexes of halogen-MPP.

\subsubsection{Phenothiazine-Bridged Porphyrin-(Hetero)Aryl Dyads}

The presence of the halogen substituent on the phenothiazine unit in $\mathrm{AB}_{3}$ type porphyrin 2a offered the possibility for further extension of the aromatic $\pi$-electronic system by Suzuki-Miyaura cross coupling reaction with (hetero)aryl-(phenothiazinyl, 7-formyl-phenothiazinyl, 9-carbazolyl-phenyl, 4-formyl-phenyl or phenyl respectively) boronic acid derivatives, which generated the phenothiazine-bridged porphyrin-(hetero)aryl dyads $\mathbf{8 - 1 2}$, whereas trans- $\mathrm{A}_{2} \mathrm{~B}_{2}$ type porphyrin $\mathbf{3 a}$ afforded the symmetric double phenothiazine-bridged porphyrin-(hetero)aryl dyads 13-15, as depicted in Scheme 3.
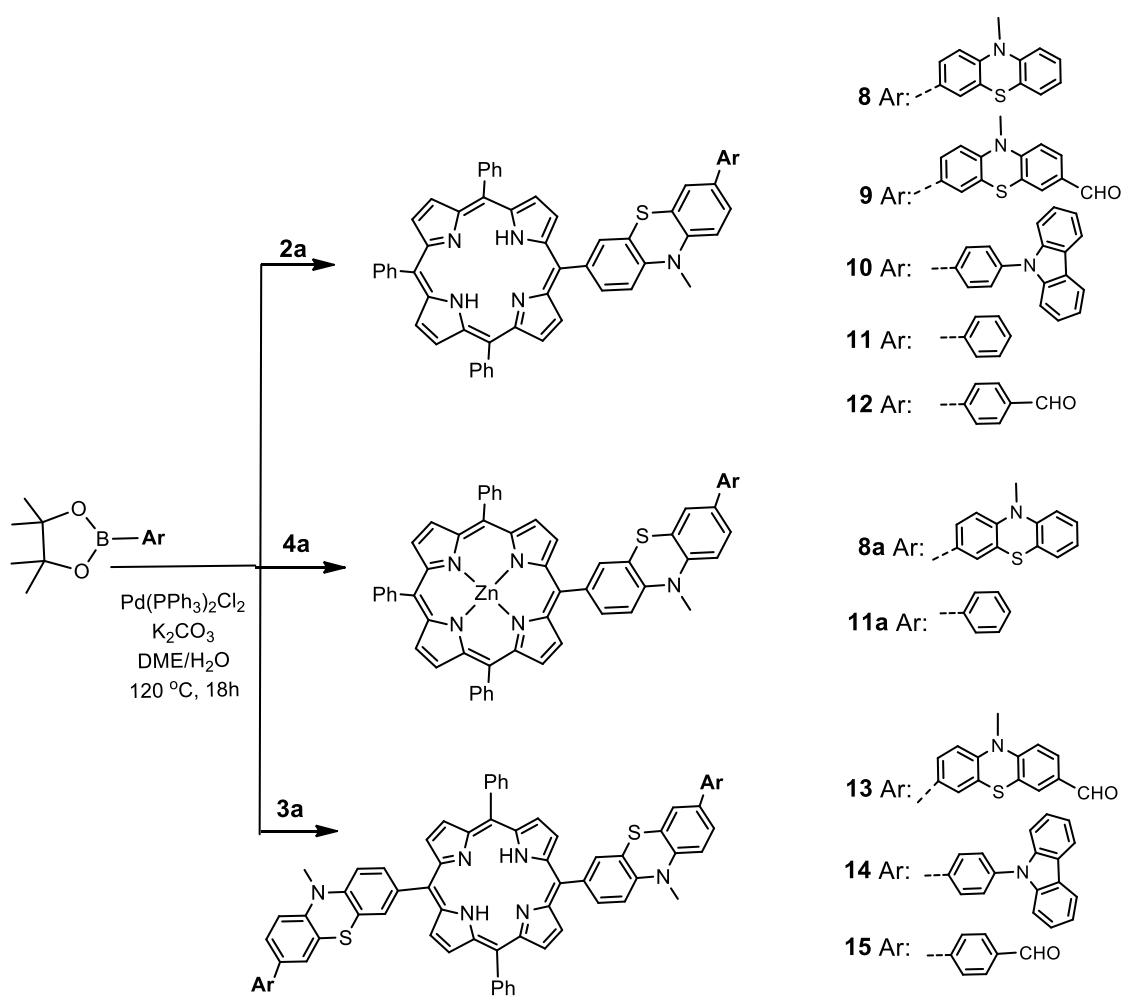

Scheme 3. Synthesis of phenothiazine-bridged porphyrin-(hetero)aryl dyads by Suzuki-Miyaura coupling between BrMPP and (hetero)arylboronic acid pinacolates.

The cross coupling reaction was proven to be successfully performed when starting with BrMPP $\mathrm{Zn}$ (II) complex 4a and phenothiazinyl-boronic acid or phenyl-boronic acid derivative respectively, 
generating the phenothiazine-bridged porphyrin-phenothiazine/phenyl dyads $\mathrm{Zn}$ (II) complexes 8a and 11a.

\subsubsection{Phenylene-Bridged Porphyrin-(Hetero)Aryl Dyads}

Under similar Suzuki-Miyaura cross coupling reaction conditions, meso-tetrakis(4-bromo-phenyl) porphyrin 16 and formyl-phenothiazine boronic ester or phenyl boronic acids (9-carbazolylphenyl-, 4-formyl-phenyl) afforded the novel $\mathrm{A}_{4}$ type phenylene-bridged porphyrin-(hetero)aryl dyads 17-19 (Scheme 4$)$ in good yields $(\sim 60 \%)$.

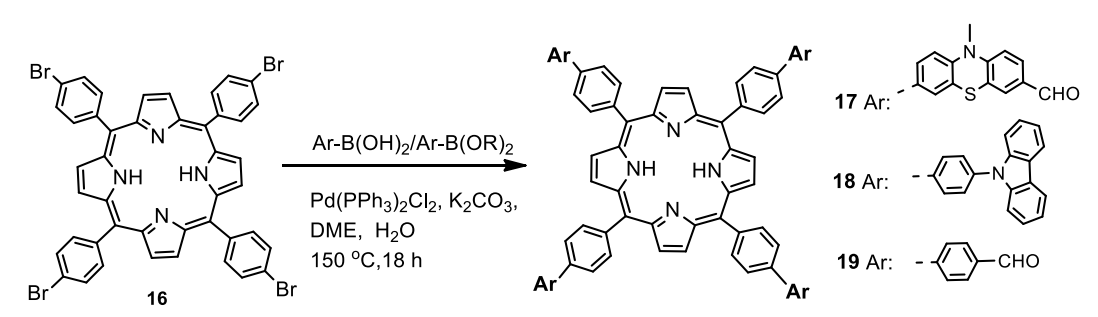

Scheme 4. Synthesis of $\mathrm{A}_{4}$ type meso-phenylene-bridged porphyrin-(hetero)aryl dyads.

For each synthesized porphyrin, the structural assignments were based on the results of high-resolution mass spectrometry, ${ }^{1} \mathrm{H}-\mathrm{NMR}$ and ${ }^{13} \mathrm{C}-\mathrm{NMR}$ spectroscopy. The key signals generated by the porphyrin inner core protons were shifted upfield $(\delta=-2.7 \mathrm{ppm})$ in the free bases and disappeared from the ${ }^{1} \mathrm{H}-\mathrm{NMR}$ spectra of metal complexes 4-7. The symmetrical structure of each of the trans- $\mathrm{A}_{2} \mathrm{~B}_{2}$ type derivatives 3 and 13-15 was unambiguously sustained by ${ }^{1} \mathrm{H}-\mathrm{NMR}$ spectra displaying four isochrone $\mathrm{AB}$ spin systems situated as low field signals $(\delta \approx 8.9 \mathrm{ppm})$ for the eight protons situated in the beta positions of the pyrrole units encrypted in the macrocyclic structure (in Supplementary Materials are presented the NMR spectra of 3a (Figures S1 and S2), 5a (Figures S3 and S4) and 13 (Figures S5-S8) well as HRMS spectra of porphyrin ligand 3a (Figure S9) and metallo complexes with $\mathrm{Zn}(\mathrm{II})$ (Figure S10), Pd(II) (Figure S11) and Cu(II) (Figure S12 and S13).

\subsection{Optical Properties of Novel MPP Dyes}

\subsubsection{UV-Vis Absorption Spectra}

The UV-Vis linear absorption optical properties of the newly synthesized porphyrin derivatives recorded in dichloromethane (DCM) solution confirmed the presence of both phenothiazine and porphyrin chromophore systems. A UV absorption band situated in the range $240-260 \mathrm{~nm}$ typical to the phenothiazine chromophore is accompanied by a strong near-UV Soret band with maxima situated in the range $418-427 \mathrm{~nm}$ followed by four low intensity $\mathrm{Q}$ bands located in the visible spectral region in the range $515-520 \mathrm{~nm}$, characteristic of the free-base etio-type porphyrin chromophore [7]. The positions of the absorption maxima for the synthesized porphyrin derivatives are depicted in Table 1 . All the compounds are characterized by a dark purple color as a consequence of the intense absorption in the Soret band region. By examining the molar absorptivity values listed in Table 1, it can be seen that halogen-MPP $2 \mathrm{a}$ and $\mathrm{A}_{4}$ type meso-phenylene-bridged porphyrin-carbazole dyad $\mathbf{1 8}$ appear well fitted for dyes applications, while the presence of the phenothiazine bridge in porphyrin-(hetero)aryl dyads 8-15 does not promote a hyperchromic effect.

As can be seen in Figure 1 depicting the UV-Vis absorption spectra of phenothiazine-bridged porphyrin phenothiazine dyads, a hyperchromic effect was recorded in the case of $\mathrm{AB}_{3}$ type dyad 9 sensitive to the presence of auxochromic formyl group, whereas in the case of symmetric substitution in trans $\mathrm{A}_{2} \mathrm{~B}_{2}$ type dyad $\mathbf{1 3}$, this hyperchromic effect appeared slightly diminished. 
Table 1. UV-Vis absorption maxima for halogen-MPP 2-3, meso-phenothiazine-bridged porphyrin-(hetero)aryl dyads $\mathrm{AB}_{3}$ type 8-12, trans $\mathrm{A}_{2} \mathrm{~B}_{2}$ type 13-15 and meso-phenylene-bridged $\mathrm{A}_{4}$ type porphyrin-(hetero)aryl dyads $17-19$ in DCM solution.

\begin{tabular}{cccc}
\hline \multirow{2}{*}{ pd } & \multicolumn{3}{c}{$\lambda_{\text {abs }}[\mathbf{n m}]$} \\
\cline { 2 - 4 } & Ptz & Soret $\varepsilon\left[\mathbf{M}^{-\mathbf{1}} \mathbf{c m}^{-\mathbf{1}}\right]$ & $\mathbf{Q}_{4,3, \mathbf{2}, \mathbf{1}}$ \\
\hline $\mathbf{2 a}$ & 259 & $420(369,256)$ & $517,554,592,652$ \\
$\mathbf{2 b}$ & 259 & $421(186,680)$ & $519,555,592,651$ \\
$\mathbf{3 a}$ & 259 & $422(134,911)$ & $519,555,592,651$ \\
$\mathbf{3 b}$ & 257 & $422(193,193)$ & $519,555,598,655$ \\
$\mathbf{8}$ & 259 & $422(61,409)$ & $519,555,598,655$ \\
$\mathbf{8 a}$ & 260 & $422(58,049)$ & 548,585 \\
$\mathbf{9}$ & 250 & $420(96,961)$ & $515,555,590,650$ \\
$\mathbf{1 0}$ & 250 & $420(79,805)$ & $515,554,590,650$ \\
$\mathbf{1 1}$ & 250 & $418(125,483)$ & $514,552,590,655$ \\
$\mathbf{1 1 a}$ & 253 & $422(72,411)$ & 548,587 \\
$\mathbf{1 2}$ & 245 & $420(191,988)$ & $515,555,585,645$ \\
$\mathbf{1 3}$ & 250 & $420(78,229)$ & $520,555,590,650$ \\
$\mathbf{1 4}$ & 245 & $420(182,215)$ & $520,555,590,650$ \\
$\mathbf{1 5}$ & 240 & $420(95,928)$ & $520,555,590,650$ \\
$\mathbf{1 7}$ & - & $423(174,035)$ & $519,548,592,652$ \\
$\mathbf{1 8}$ & - & $420(660,743)$ & $515,550,590,645$ \\
$\mathbf{1 9}$ & - & $427(78,383)$ & $516,555,592,642$ \\
\hline
\end{tabular}

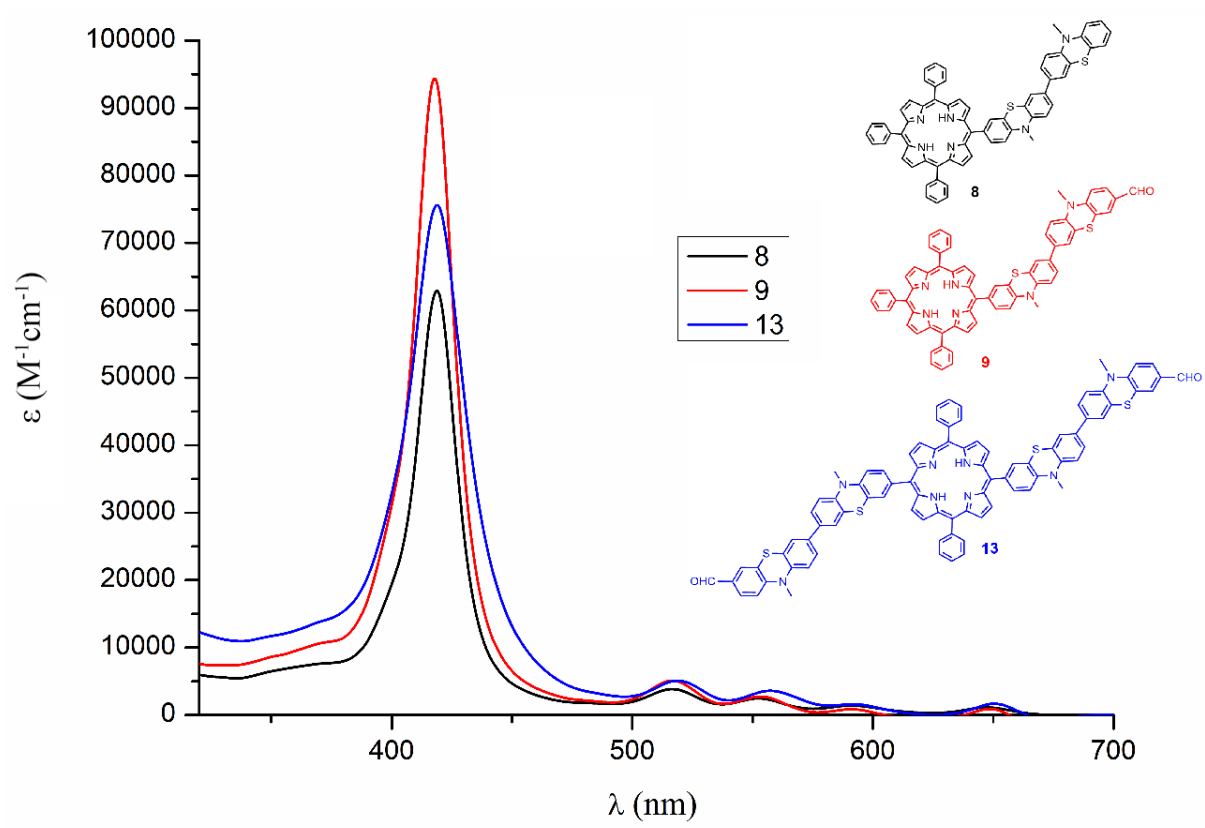

Figure 1. UV-Vis absorption spectra of phenothiazine-bridged porphyrin-phenothiazine dyads in DCM solution.

The characteristic UV-Vis absorption maxima recorded in solution for the prepared metal complexes of halogen-MPP are indicated in Table 2. As compared to the corresponding free base ligand, the electronic spectrum of each metal-complex displayed in the near UV range an intense Soret band without important shifting of its maxima position and in the visible region one or two Q bands, indicative of successful metal insertion in a square planar geometry [8]. 
Table 2. UV-Vis linear optical properties of metal complexes of bromoMPP $(4,5)$ and chloroMPP $(6,7)$ in DCM solution.

\begin{tabular}{|c|c|c|c|}
\hline \multirow{3}{*}{ Cpd * } & \multicolumn{2}{|c|}{ Phenothiazine } & \multirow{2}{*}{$\begin{array}{c}\text { Porphyrin } \\
\lambda[\mathrm{nm}]\end{array}$} \\
\hline & $\lambda[\mathrm{nm}]$ & $\lambda[\mathrm{nm}]$ & \\
\hline & & $\begin{array}{c}\text { Soret } \\
\varepsilon\left[\mathbf{M}^{-1} \mathrm{~cm}^{-1}\right]\end{array}$ & $Q_{\text {alfa, beta }}$ \\
\hline $4 a$ & 255 & $425(146,756)$ & 550,595 \\
\hline $4 b$ & 261 & $418(215,712)$ & 524,589 \\
\hline $4 c$ & 255 & $425(156,953)$ & 555,595 \\
\hline $4 d$ & 257 & $416(277,707)$ & 538,583 \\
\hline $5 a$ & 256 & $422(222,108)$ & 539,589 \\
\hline $5 b$ & 257 & $418(73,993)$ & 524,589 \\
\hline $5 c$ & 256 & $416(201,024)$ & 538,583 \\
\hline $5 d$ & 256 & $416(160,106)$ & 539,583 \\
\hline $6 a$ & 250 & $425(108,260)$ & 555,600 \\
\hline $6 b$ & 259 & $422(212,575)$ & 526 \\
\hline $6 c$ & 260 & $425(235,777)$ & 550,595 \\
\hline $6 d$ & 259 & $419(207,318)$ & 542,587 \\
\hline $7 a$ & 257 & $425(193,910)$ & 552,593 \\
\hline $7 \mathrm{~b}$ & 256 & $417(208,454)$ & 524 \\
\hline $7 c$ & 257 & $418(310,212)$ & 531 \\
\hline $7 d$ & 257 & $418(219,339)$ & 526 \\
\hline
\end{tabular}

* Labeling of metal complexes: a Zn(II), b Pd(II), c Ni(II), d Cu(II).

\subsubsection{UV-Vis Fluorescence Emission Spectra}

Upon irradiation around the $\lambda_{\max }$ corresponding to Soret band, in solution, phenothiazine-bridged porphyrin-(hetero)aryl dyads displayed fluorescence with noticeable Stokes shifts (above $8000 \mathrm{~cm}^{-1}$ ) and quantum yields between 0.08 and 0.19 when measured against TPP standard, as depicted in Table 3.

Table 3. Fluorescence emission spectral data of the synthesized phenothiazine-bridged porphyrin-(hetero)aryl dyads.

\begin{tabular}{cccc}
\hline Compounds & $\lambda \mathrm{em}^{a}[\mathrm{~nm}]$ & Stokes Shift $\left[\mathbf{c m}^{-\mathbf{1}}\right]$ & ${ }_{\boldsymbol{\phi F}}{ }^{\boldsymbol{b}}$ \\
\hline $\mathbf{9}$ & 655 & 8542 & 0.16 \\
$\mathbf{1 0}$ & 657 & 8588 & 0.14 \\
$\mathbf{1 2}$ & 654 & 8519 & 0.18 \\
$\mathbf{1 3}$ & 659 & 8635 & 0.19 \\
$\mathbf{1 4}$ & 652 & 8472 & 0.08 \\
$\mathbf{1 5}$ & 658 & 8612 & 0.15 \\
\hline
\end{tabular}

In Figure 2 are the emission spectra of phenothiazine-bridged porphyrin dyads containing phenothiazine 9 and $\mathbf{1 3}$ and carbazole $\mathbf{1 4}$ moieties, emphasizing the fluorophore properties of the symmetrical trans $\mathrm{A}_{2} \mathrm{~B}_{2}$ type phenothiazine-bridged porphyrin-phenothiazine dyad 13.

The presence of the phenothiazine units in dye scaffolds may be considered as responsible on one hand for the energy dissipation by typical butterfly vibrations, thereby inducing low fluorescence emission in solution, but on the other hand, for enlarging the intermolecular distance due to its bent structure, thereby preventing the intermolecular $\pi-\pi$ stacking and subsequently stimulating fluorescence in the aggregated state [28]. In solution, the parent MPP dyes displayed fluorescence emissions typical to the porphyrin core in 660-670 $\mathrm{nm}$ range [7], while the extension of the pending phenothiazine arms of $\mathrm{A}_{3} \mathrm{~B}$ type and $\mathrm{A}_{2} \mathrm{~B}_{2}$ type MPP with additional peripheral phenothiazine or phenyl 
units produced fluorescence quenching in compounds $\mathbf{8}$, and $\mathbf{1 1}$. The presence of formyl auxochromic groups in peripheral positions appeared beneficial by imparting molecular polarization via an electron withdrawing effect, and thus fluorescence emissions were recorded for compounds 9, 12, 13 and 15, as shown in Table 3. Phenothiazine-bridged porphyrin-carbazole dyads $A_{3} B$ type 10 and $A_{2} B_{2}$ type 14 displayed fluorescence emissions in similar range. The symmetrical $\mathrm{A}_{4}$ type phenylene-bridged porphyrin-(hetero)aryl dyads did not display fluorescence emission regardless the nature of the peripheral units: formyl-phenothiazine 17, N-phenyl carbazole 18 and phenyl-carbaldehyde 19.

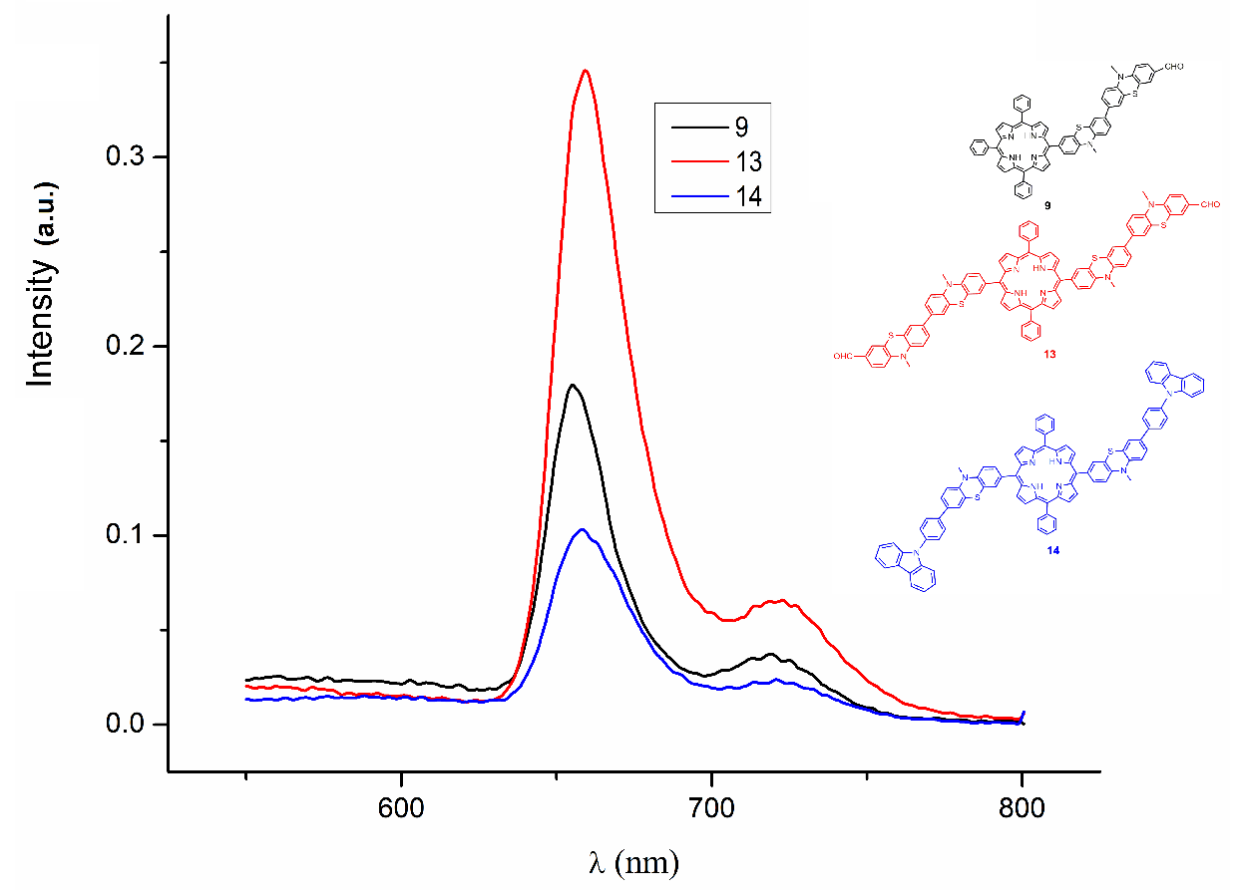

Figure 2. Emission spectra of phenothiazine-bridged porphyrin dyads containing phenothiazine 9 and 13 and carbazole 14 moieties after excitation at $420 \mathrm{~nm}$.

\subsection{Biological Activity Evaluation of Phenothiazine-Bridged Porphyrin-Phenothiazine Dyad Fluorescent Dyes} 9, 13 and 15

Pursuing our goal of enabling the distinct visualization of human ovarian tumors, fluorescent dyes 9,13 and 15 (Table 3) displaying fluorescence emission in solution above $650 \mathrm{~nm}$ and containing the carbaldehyde functional units susceptible to passing on the affinity towards the bio-materials were examined in vitro in terms of their cytotoxicity and their capacity for staining living cells by subcellular localization in human ovarian tumor A2780, cisplatin-resistant ovarian adenocarcinoma cells A2780cis and OVCAR-3 cell lines.

\subsubsection{MTT Colorimetric Assay}

The cells' viability was tested using the MTT colorimetric assay (dye 3-(4,5-dimethylthiazol-2-yl)-2,5-diphenyltetrazolium bromide) following a previously reported colorimetric protocol [29]. Separate serial dilutions of each dye 9, $\mathbf{1 3}$ and $\mathbf{1 5}$ were employed in the treatment of ovarian adenocarcinoma cells lines under study. The modification in cell viability was observed by monitoring the concentration of the purple formazan formed after $24 \mathrm{~h}$ of incubation and reflected by the recorded optical density (OD) of the sample. The cells' viability was expressed as percentage of survival in treated versus untreated (control) cell populations, and the results are shown in Table 4. 
Table 4. Survival rate of ovarian adenocarcinoma cells treated with serial concentrations of $\mathbf{9 , 1 3}$ and $\mathbf{1 5}$ respectively, versus the untreated reference cell population expressed as median values \pm standard errors of means (SEM)

\begin{tabular}{|c|c|c|c|c|c|c|c|c|}
\hline Compound & & & & & & & & \\
\hline Conc. $[\mu \mathrm{M}]$ & 240.00 & 120.00 & 60.00 & 30.00 & 15.00 & 7.50 & 3.75 & 1.88 \\
\hline $\begin{array}{c}\% \text { cell survival } \\
\text { A2780 }\end{array}$ & $59.40 \pm 2.40$ & $80.83 \pm 3.28$ & $77.56 \pm 3.56$ & $79.87 \pm 4.60$ & $89.87 \pm 3.76$ & $91.30 \pm 3.47$ & $90.60 \pm 4.35$ & $94.00 \pm 4.51$ \\
\hline A2780cis & $90.38 \pm 2.74$ & $92.45 \pm 2.58$ & $92.96 \pm 1.45$ & $102.00 \pm 1.55$ & $95.00 \pm 3.11$ & $99.27 \pm 2.39$ & $92.46 \pm 3.72$ & $89.30 \pm 1.20$ \\
\hline OVCAR 3 & $56.94 \pm 3.61$ & $69.58 \pm 3.68$ & $83.68 \pm 4.50$ & $76.36 \pm 4.17$ & $83.02 \pm 3.58$ & $82.89 \pm 4.18$ & $80.82 \pm 5.12$ & $87.81 \pm 4.14$ \\
\hline Compound & \multicolumn{8}{|c|}{13} \\
\hline Conc. $[\mu \mathrm{M}]$ & 210.00 & 105.00 & 52.50 & 26.25 & 13.13 & 6.56 & 3.28 & 1.64 \\
\hline $\begin{array}{c}\% \text { cell survival } \\
\text { A2780 }\end{array}$ & $62.00 \pm 0.95$ & $75.77 \pm 1.04$ & $93.07 \pm 3.10$ & $95.51 \pm 2.36$ & $93.57 \pm 2.92$ & $100.06 \pm 1.60$ & $98.43 \pm 3.36$ & $100.23 \pm 0.39$ \\
\hline A2780cis & $94.06 \pm 3.72$ & $99.75 \pm 1.42$ & $98.00 \pm 2.30$ & $100.37 \pm 4.15$ & $97.12 \pm 3.46$ & $95.04 \pm 3.39$ & $101.00 \pm 1.73$ & $100.85 \pm 2.54$ \\
\hline OVCAR 3 & $44.14 \pm 3.46$ & $66.89 \pm 4.35$ & $73.07 \pm 2.80$ & $75.21 \pm 4.09$ & $82.19 \pm 4.91$ & $82.65 \pm 2.45$ & $85.37 \pm 4.18$ & $89.92 \pm 2.27$ \\
\hline Compound & \multicolumn{8}{|c|}{15} \\
\hline Conc. $[\mu \mathrm{M}]$ & 250.00 & 125.00 & 62.50 & 31.25 & 15.63 & 7.81 & 3.91 & 1.95 \\
\hline $\begin{array}{c}\% \text { cell survival } \\
\text { A2780 }\end{array}$ & $66.46 \pm 1.78$ & $82.30 \pm 3.62$ & $87.73 \pm 1.74$ & $92.17 \pm 0.64$ & $92.03 \pm 1.17$ & $95.26 \pm 5.13$ & $94.13 \pm 3.25$ & $98.34 \pm 2.11$ \\
\hline A2780cis & $93.38 \pm 3.18$ & $96.29 \pm 1.45$ & $92.00 \pm 1.15$ & $102.00 \pm 2.88$ & $97.05 \pm 1.16$ & $99 \pm 2.31$ & $86.85 \pm 1.15$ & $89 \pm 2.52$ \\
\hline OVCAR 3 & $44.51 \pm 3.67$ & $64.41 \pm 4.84$ & $80.26 \pm 3.75$ & $83.20 \pm 5.65$ & $79.65 \pm 3.38$ & $85.89 \pm 6.53$ & $101.45 \pm 5.59$ & $94.11 \pm 6.73$ \\
\hline
\end{tabular}


A close inspection of the data in Table 4 suggested that there were no significant differences between the cytotoxicity of the tested dyes 9,13 and 15, each of them exhibiting a moderate toxicity on ovarian tumor cell lines in vitro (one-way analysis of variances, Bonferroni post-test, in the $95 \%$ confidence interval). From the viewpoint of the cell's growth inhibition, A2780cis was the most resistant, while the folate receptor-rich OVCAR-3 cell line appeared the most susceptible to being affected.

\subsubsection{Alamar Blue Assay}

The metabolic activity of the ovarian adenocarcinoma cells lines under study was evaluated by the Alamar Blue fluorimetric test [30] in the presence of dyes 9, 13 and 15 using the same eight serial dilutions ranging from about 250 to $2 \mu \mathrm{M}$ employed in the MTT colorimetric assay (Table 4). After $24 \mathrm{~h}$ of incubation, the nonfluorescent Alamar Blue dye was reduced by cell metabolic activity to the pink fluorescent resofurin dye (excitation at $570 \mathrm{mn}$, emission detected at $585 \mathrm{~nm}$ ). In Figure 3 , the correlation between fluorescence intensity and concentration for the tested fluorescent dyes against ovarian adenocarcinoma cells A2780 is shown. (In the Supplementary Material there is a similar correlation for ovarian adenocarcinoma A2780cis (Figure S14) and OVCAR3 cells (Figure S15).

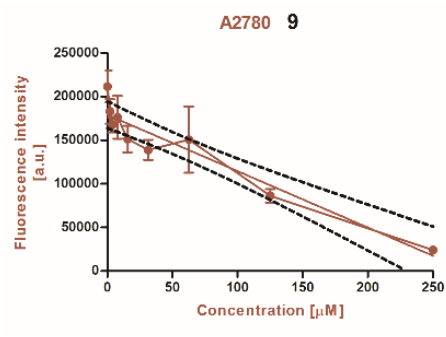

(a)

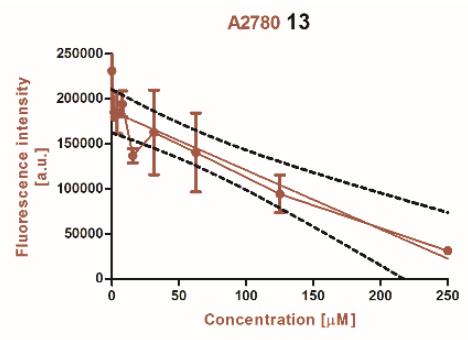

(b)

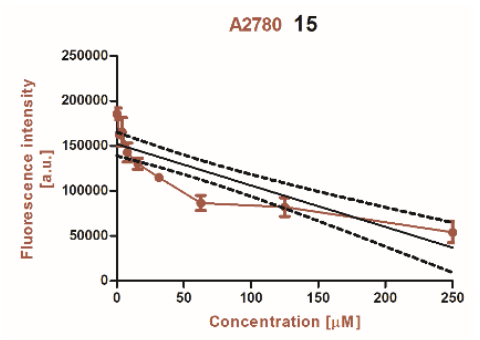

(c)

Figure 3. Linear regression of the metabolic rate of ovarian cancer cell line A2780 versus the concentrations of the fluorescent dyes: (a) 9, (b) 13 and (c) 15.

The data provided by the fluorescence assessment were used to build a linear regression of dose-response relationship for each tested compound, and to quantify the results with the mathematic parameter hillslope, as presented in Table 5 .

Table 5. The capacities of 9,13 and 15 compounds to reduce the metabolic potential of treated ovarian tumor cells in vitro, quantified through the mathematic parameter hillslope, derived from the linear regression of the dose-response relationship (concentration of compounds versus fluorescence intensity).

\begin{tabular}{cccccc}
\hline \multirow{2}{*}{ Cpd } & \multirow{2}{*}{ Cell Lines } & \multicolumn{4}{c}{ Linear Regression Data } \\
\cline { 3 - 6 } & & Slope & Goodness of Fit $\left.\mathbf{( R}^{\mathbf{2}}\right)$ & $p$ Value & Deviation from Zero \\
\hline \multirow{3}{*}{$\mathbf{9}$} & OVCAR-3 & $-344.8 \pm 30.66$ & 0.83 & $<0.0001$ & Significant \\
& A2780 & $-646.9 \pm 77.62$ & 0.74 & $<0.0001$ & Significant \\
& A2780cis & $-459.7 \pm 42.01$ & 0.86 & $<0.0001$ & Significant \\
\hline \multirow{2}{*}{$\mathbf{1 3}$} & OVCAR-3 & $-275.7 \pm 32.17$ & 0.75 & $<0.0001$ & Significant \\
& A2780 & $-655.4 \pm 119.1$ & 0.56 & $<0.0001$ & Significant \\
& A2780cis & $-567.1 \pm 58.13$ & 0.82 & $<0.0001$ & Significant \\
\multirow{2}{*}{$\mathbf{1 5}$} & OVCAR-3 & $-169.0 \pm 23.17$ & 0.68 & $<0.0001$ & Significant \\
& A2780 & $-460.7 \pm 64.12$ & 0.69 & $<0.0001$ & Significant \\
& A2780cis & $-361.1 \pm 53.16$ & 0.71 & $<0.0001$ & Significant \\
\hline
\end{tabular}

The deepest drops in metabolic rate, represented by negative hillslopes (Table 5) have been recorded for cisplatin-sensitive A2780 (-655.4) and cisplatin-resistant A2780cis (-567.1) cell lines subsequent to the treatment with 13 , while for the folate-rich OVCAR-3 cell line, the largest metabolic rate reduction was caused by $9(-344.8)$. 


\subsubsection{Cell Fluorescence Imaging}

Fluorescence microscopy became an indispensable tool in single-molecule investigations, providing a high signal-to-noise ratio for visualization while still retaining the key features in the physiological context of native biological systems [31]. Fluorescent porphyrin derivatives characterized by large Stokes shift between absorption $(\sim 400 \mathrm{~nm})$ and red/NIR emission were prospected in the fluorescence detection in various tissues or in vivo. In order to prevent the aggregation caused quenching effect due to $\pi-\pi$ stacking aggregation favored by the planarity of the aromatic structure of the macrocycle, one chemical approach was to introduce various bulky groups as substituents of the porphyrin core [32]. Fluorescence imaging was carried out in order to investigate the internalization pathways of the selected fluorescent dyes 9, 13 and 15 inside the tested ovarian adenocarcinoma cells. The typical chemical reactivity of the carbaldehyde unit was the selected structural feature meant for passing on the affinity towards the bio-materials. In phenothiazine-bridged porphyrin-phenothiazine dyads $A_{3} B$ type 9 and $A_{2} B_{2}$ type 13 the formyl group was attached to the bent phenothiazine unit(s) prone to prevent the intermolecular $\pi-\pi$ stacking, and green fluorescence was displayed by these staining agents in the aggregated state. Dye $\mathbf{1 5}$ containing the formyl group attached to peripheral flat phenylene units exhibited aggregation-caused fluorescence quenching, which limited its application.

The fluorescent dye concentration applied for cells staining was $50 \mu \mathrm{M}$ estimated and was well fitted for both fluorescence visualization and avoidance of cytotoxicity effects responsible for reducing the cell viability. Figure 4 illustrates the A2780cis cells in a typical Bright-field image (Figure 4a); their corresponding fluorescence imaging after the standard nuclei staining with DAPI (4',6-diamidino-2-phenylindole) (Figure 4b); and fluorescence imaging after staining with fluorescent dye 13 (Figure $4 \mathrm{c}$ ).

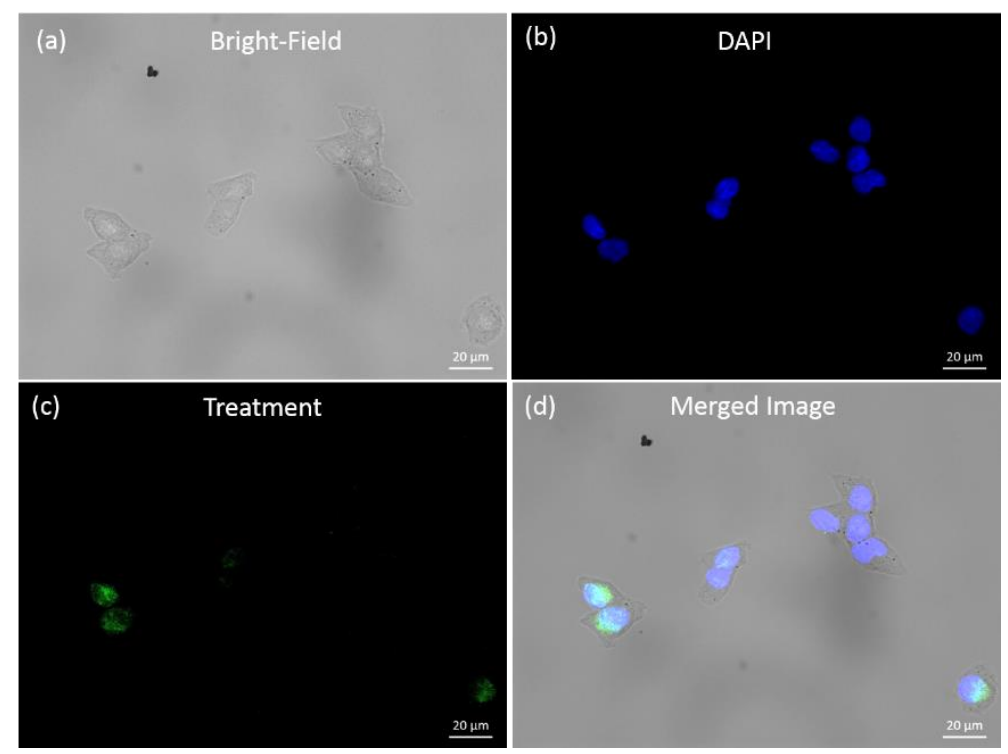

Figure 4. Images of A2780cis cells: (a) Bright-field image (63x iris oil immersion objective). (b) Fluorescence images after staining with DAPI (G 365 excitation filter). (c) Fluorescence images after staining with 13 (excitation filter BP 470/40): (d) merged fluorescence images (b,c).

The merged fluorescence image presented in Figure $4 \mathrm{~d}$ reveals the green fluorescent signal of dye 13 overlain with the blue fluorescent signal of DAPI distributed inside the cells. This result allows us to conclude that fluorescent dye $\mathbf{1 3}$ is able to accumulate both in the perinuclear and the nuclei region of the ovarian adenocarcinoma cells, being susceptible to crossing the nucleus membrane.

In order to confirm the cellular uptake of dye 13, we further invoked two photon excited-fluorescence lifetime imaging (TPE-FLIM), an ideal non-invasive technique for live-cell imaging, which offers multiple advantages over linear optical microscopy, including acquisition of 
fluorescence image with deep light penetration generated by NIR excitation, less photodamage of living organism and negligible background signal [33]. In recent literature, functional porphyrins were specified as potential fluorescent probes for TPE fluorescence imaging of various tumoral cells. Thus, 2-acetyl-6-dimethyl-aminonaphthalene-porphyrin dyads, characterized by intramolecular fluorescence resonance energy transfer process (FRET) from the aminonaphthalene donor to the porphyrin acceptor unit, were employed for TPE fluorescence imaging of lung cancer A549 cells under the irradiation with a $740 \mathrm{~nm}$ femtosecond laser [34,35]. Mesoporous silica nanocomposites containing the photosensitizer 5,10,15,20-tetrakis-(1-methyl-4-pyridinio)porphyrin-tetra-( $p$-toluenesulfonate) were employed for targeted TPE-FLIM of human breast carcinoma cell line MCF-7 and the human lung cancer A549 cell line [36]. A non-covalent complex of lipid-coated semiconductor CdSe/ZnS quantum dots with a partially hydrogenated porphyrin (chlorin e6) photosensitizer was imaged within plasma membrane and intracellular compartments of living HeLa cells [37]. In our experiments, the chosen wavelength of the excitation laser was $800 \mathrm{~nm}$, ensuring that the combined energy of two photons spanned the gap between the ground state and first excited electronic state of the fluorescent dye 13 . Figure 5 illustrates the bright field image corresponding to A 2780 cells (Figure $5 \mathrm{a}$ ) and the TPE-FLIM image where the contrast is based on the lifetime of the fluorophore $\mathbf{1 3}$ after staining A 2780 cells (Figure 5b).

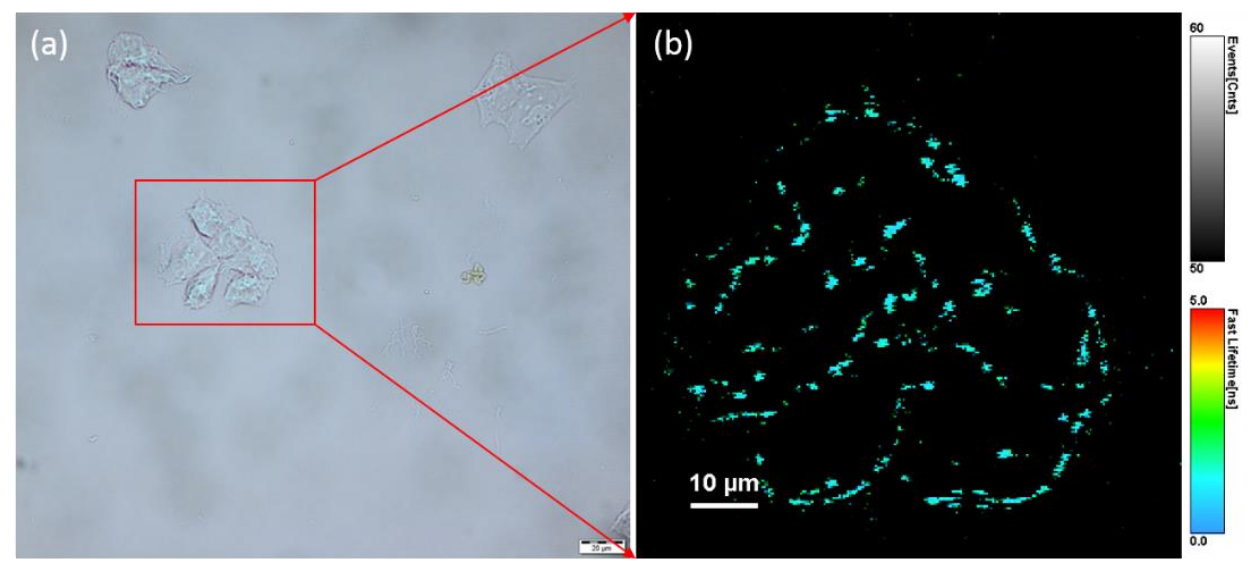

Figure 5. Microscopy imaging of A 2780 cells: (a) Bright-field image (63x iris oil immersion objective). (b) TPE-FLIM image after incubation for $24 \mathrm{~h}$ with dye 13 (time-resolved confocal fluorescence microscope system coupled to a Ti:Sa tunable femtosecond laser at $800 \mathrm{~nm}$, using up to $25 \mathrm{~mW}$ of the laser beam's power).

The collected TPE-FLIM image presents the successful molecular binding of the dye $\mathbf{1 3}$ inside A2780 cells, giving the possibility of a distinct visualization of ovarian adenocarcinoma cells in NIR light.

\section{Materials and Methods}

\subsection{Spectral Measurements}

The mass spectra were recorded on a HRMS spectrometer LTQ Orbitrap XL-Thermo-Scientific (Waltham, MA, USA) using APCI or ESI ionization technique. NMR spectra were recorded at room temperature on Bruker Avance instruments (Bruker BioSpin $\mathrm{GmbH}$, Rheinstetten, Germany) $\left({ }^{1} \mathrm{H} /{ }^{13} \mathrm{C}\right.$ : $400 \mathrm{MHz} / 100 \mathrm{MHz}$ or $600 \mathrm{MHz} / 150 \mathrm{MHz}$ ) in solution (deuterated solvents chloroform $\left(\mathrm{CDCl}_{3}\right.$ ) or DMSO). UV-Vis spectra were recorded in $\mathrm{CH}_{2} \mathrm{Cl}_{2}$ with a Perkin Elmer Lambda 35 spectrophotometer (Waltham (HQ), MA, USA). Fluorescence spectra in solution were recorded in DCM with a Perkin Elmer PL 55 spectrophotometer (Waltham (HQ), MA, USA). The fluorescence quantum yield was calculated using tetraphenylporphyrin (TPP) standard $\Phi=0.13 \%$ in DCM solution [38]. 


\subsection{Reagents}

Phenothiazine, 2-chlorophenothiazine and phenylboronic acid were purchased from Sigma Aldrich; 10-methyl-7-(4,4,5,5-tetramethyl-1,3,2-dioxaborolan-2-yl)-10H-phenothiazine-3-carbaldehyde was prepared according to the procedure described in the literature [39].

(4-(9H-carbazol-9-yl)phenyl)boronic acid was prepared according to the procedure described in the literature [40].

5,10,15,20-tetrakis(4-bromophenyl)-21H,23H-porphine was prepared according to the procedure described in the literature [41].

\section{8-Cloro-3-formyl-10-methyl-phenothiazine $\mathbf{1 b}$}

To a cooled solution $\left(0{ }^{\circ} \mathrm{C}\right)$ containing DMF $(10 \mathrm{~mL})$ and $\mathrm{POCl}_{3}(12 \mathrm{~mL})$, 2-chloro-10-methyl-10H-phenothiazine $(30 \mathrm{~g}, 0.12 \mathrm{~mol})$ dissolved in 1,2-dichloroethane $(150 \mathrm{~mL})$ was added, and the reaction mixture was heated at $85^{\circ} \mathrm{C}$ for $6 \mathrm{~h}$. The reaction mixture was poured into cold water $(200 \mathrm{~mL})$ and extracted with ethyl-acetate $(2 \times 200 \mathrm{~mL})$. The extract was dried over anhydrous magnesium sulfate and the solvent was removed till dryness. The product was purified by column chromatography, using a silica gel solid support and toluene as eluent. Yellow powder, yield $48 \%(16.1 \mathrm{~g}),{ }^{1} \mathrm{H}-\mathrm{NMR}\left(400 \mathrm{MHz}, \mathrm{CDCl}_{3}\right) \delta \mathrm{ppm} 3.44\left(\mathrm{~s}, 3 \mathrm{H}, \mathrm{CH}_{3}\right), 6.81\left(\mathrm{~d}, 1 \mathrm{H},{ }^{4} \mathrm{~J}=1.9 \mathrm{~Hz}\right), 6.88(\mathrm{dd}, 1 \mathrm{H}$, $\left.{ }^{3} J=6.4 \mathrm{~Hz},{ }^{4} J=1.9 \mathrm{~Hz}\right), 6.97\left(\mathrm{~d} \mathrm{1H},{ }^{3} J=6.4 \mathrm{~Hz}\right), 7.03\left(\mathrm{~d}, 1 \mathrm{H},{ }^{3} J=6.8 \mathrm{~Hz}\right), 7.60\left(\mathrm{~d}, 1 \mathrm{H},{ }^{4} J=1.8 \mathrm{~Hz}\right), 7.68$ $\left(\mathrm{dd}, 1 \mathrm{H},{ }^{3} \mathrm{~J}=6.8 \mathrm{~Hz}^{4} \mathrm{~J}=1.8 \mathrm{~Hz}\right), 9.81(\mathrm{~s}, 1 \mathrm{H}, \mathrm{CHO}) ;{ }^{13} \mathrm{C}-\mathrm{NMR}\left(100 \mathrm{MHz}, \mathrm{CDCl}_{3}\right) \delta \mathrm{ppm} 35.9\left(\mathrm{~N}_{-} \mathrm{CH}_{3}\right)$, $114.1,115.2,121.0\left(\mathrm{C}_{\mathrm{q}}\right), 123.4\left(\mathrm{C}_{\mathrm{q}}\right), 123.8,127.8,127.9,130.6,131.5\left(\mathrm{C}_{\mathrm{q}}\right), 133.7\left(\mathrm{C}_{\mathrm{q}}\right), 145.3\left(\mathrm{C}_{\mathrm{q}}\right), 150.3\left(\mathrm{C}_{\mathrm{q}}\right)$, $190.0(\mathrm{CHO})$.

3.2.1. General Procedure for the Synthesis of $\mathrm{AB}_{3}$ and $\mathrm{A}_{2} \mathrm{~B}_{2}$-Type Meso-HalogenophenothiazinylPorphyrins (2 and 3 )

Propionic acid $(100 \mathrm{~mL})$ and acetic anhydride $(3 \mathrm{~mL})$ were stirred and heated at $110^{\circ} \mathrm{C}$ for $1 \mathrm{~h}$. After cooling at room temperature, benzaldehyde $(12 \mathrm{mmol}), 10$-methyl- $10 \mathrm{H}$-phenothiazinyl-carbaldehyde derivative $(12 \mathrm{mmol})$ and pyrrole $(24 \mathrm{mmol})$ were added and the mixture was heated at $110^{\circ} \mathrm{C}$ for $4 \mathrm{~h}$. After completion, the obtained purple crystals were collected by filtration and washed with methanol to remove the traces of propionic acid. In the case in which the product did not precipitate, the solvent was removed by reduced pressure distillation and the residue was washed with methanol. The separation by column chromatography on silica gel gave the corresponding meso-halogenophenothiazinyl-porphyrins (2) and (3) respectively.

\section{5,10,15-triphenyl-20-(7-bromo-10-methyl-10H-phenothiazin-3-yl)-21,23H-porphyrin 2a}

Starting with bromo-phenothiazine carbaldehyde $1 \mathrm{a}(4 \mathrm{~g}, 0.012 \mathrm{~mol})$, benzaldehyde $(1.3 \mathrm{~mL}, 0.012 \mathrm{~mol})$, pyrrole $(1.7 \mathrm{~mL}, 0.024 \mathrm{~mol})$, propionic acid $(100 \mathrm{~mL})$ and acetic anhydride $(3 \mathrm{~mL})$ were added, and after purification by column chromatography using dichloromethane/petrol ether (2:1) as eluent, a purple powder was obtained; yield $18 \%(0.9 \mathrm{~g}) .{ }^{1} \mathrm{H}-\mathrm{NMR}\left(400 \mathrm{MHz}, \mathrm{CDCl}_{3}\right) \delta \mathrm{ppm}$ $-2.73(\mathrm{~s}, 2 \mathrm{H}, \mathrm{NH}), 3.60(\mathrm{~s}, 3 \mathrm{H}), 6.85(\mathrm{~d}, 1 \mathrm{H}, J=7.4 \mathrm{~Hz}), 7.15(\mathrm{~d}, 1 \mathrm{H}, J=7.4 \mathrm{~Hz}), 7.37-7.40(\mathrm{~m}, 2 \mathrm{H})$, $7.78-7.83(\mathrm{~m}, 9 \mathrm{H}), 8.01-8.05(\mathrm{~m}, 2 \mathrm{H}), 8.25(\mathrm{~d}, 6 \mathrm{H}, J=7.2 \mathrm{~Hz}), 8.86-8.89(\mathrm{~m}, 6 \mathrm{H}), 8.92(\mathrm{~d}, 2 \mathrm{H}, J=4.5 \mathrm{~Hz})$; ${ }^{13} \mathrm{C}-\mathrm{NMR}\left(100 \mathrm{MHz}, \mathrm{CDCl}_{3}\right) \mathrm{ppm} 35.6,112.5,115.0,115.4,118.7(\mathrm{Cq}), 120.2(4 \mathrm{Cq}), 121.2(\mathrm{Cq}), 125.5(\mathrm{Cq})$, 126.7 (9C), 127.7 (6C), 129.7, 130.3 (2Cq), 132.9, 134.0, 134.5 (8C), 136.8 (Cq), 142.1 (8Cq), 145.0 (3Cq). HRMS-APCI calcd. for: $\mathrm{C}_{51} \mathrm{H}_{35} \mathrm{BrN}_{5} \mathrm{~S}[\mathrm{M}+\mathrm{H}]^{+}$828.1717; found: 828.1791.

\section{5,10,15-triphenyl-20-(2-chloro-10-methyl-10H-phenothiazin-7-yl)-21,23H-porphyrin 2b}

Starting with phenothiazine carbaldehyde $1 \mathrm{~b}(4 \mathrm{~g}, 0.012 \mathrm{~mol})$, benzaldehyde $(1.3 \mathrm{~mL}, 0.012 \mathrm{~mol})$, pyrrole $(1.7 \mathrm{~mL}, 0.024 \mathrm{~mol})$, propionic acid $(100 \mathrm{~mL})$ and acetic anhydride $(3 \mathrm{~mL})$, a mixture of $2 \mathrm{~b}$ and $3 \mathrm{~b}$ was obtained. After separation by column chromatography using chloroform/heptane (2:1) as eluent, $2 \mathrm{~b}$ was obtained as a purple powder; yield $14 \%(0.4 \mathrm{~g}) ;{ }^{1} \mathrm{H}-\mathrm{NMR}\left(600 \mathrm{MHz}, \mathrm{CDCl}_{3}\right) \delta \mathrm{ppm}$ $-2.76(\mathrm{~s}, 2 \mathrm{H}, \mathrm{NH}), 3.66(\mathrm{~s}, 3 \mathrm{H}), 7.01(\mathrm{~s}, 1 \mathrm{H}), 7.04(\mathrm{~d}, 1 \mathrm{H}, J=7.9 \mathrm{~Hz}), 7.18(\mathrm{~d}, 1 \mathrm{H}, J=8.1 \mathrm{~Hz}), 7.21(\mathrm{~d}, 1 \mathrm{H}, J$ 
$=7.9 \mathrm{~Hz}), 7.78-7.82(\mathrm{~m}, 9 \mathrm{H}), 8.02-8.06(\mathrm{~m}, 2 \mathrm{H}), 8.24(\mathrm{~d}, 6 \mathrm{H}, J=8.2 \mathrm{~Hz}), 8.87(\mathrm{~d}, 6 \mathrm{H}, J=4.2 \mathrm{~Hz}), 8.91$ $(\mathrm{d}, 2 \mathrm{H}, J=4.2 \mathrm{~Hz}) ;{ }^{13} \mathrm{C}-\mathrm{NMR}\left(150 \mathrm{MHz}, \mathrm{CDCl}_{3}\right) \delta \mathrm{ppm} 35.7,112.6,114.8,118.7(\mathrm{Cq}), 120.21,120.23$ $(\mathrm{Cq}), 121.6(\mathrm{Cq}), 121.8(\mathrm{Cq}), 122.5,126.7(9 \mathrm{C}), 127.7(6 \mathrm{C}), 127.9(3 \mathrm{Cq}), 128.2(\mathrm{Cq}), 129.0(\mathrm{Cq}), 132.9,133.7$ (2Cq), 133.9, 134.5 (8C), 137.0 (2Cq), 142.1 (4Cq), 144.8 (2Cq), 147.0 (2Cq). HRMS-APCI calcd. for: $\mathrm{C}_{51} \mathrm{H}_{35} \mathrm{ClN}_{5} \mathrm{~S}[\mathrm{M}+\mathrm{H}]^{+}$783.2223; found: 783.2206.

5,15-diphenyl-10,20-bis(7-bromo-10-methyl-10H-phenothiazin-3-yl)-21,23H-porphyrin 3a

Purification by column chromatography using dichloromethane/petrol ether (2:1) as eluent gave a purple powder; yield 12\% (0.8 g); ${ }^{1} \mathrm{H}-\mathrm{NMR}\left(400 \mathrm{MHz}, \mathrm{CDCl}_{3}\right) \delta \mathrm{ppm}-2.75,(\mathrm{~s}, 2 \mathrm{H}, \mathrm{NH}), 3.58(\mathrm{~s}, 6 \mathrm{H})$, $6.83(\mathrm{~d}, 2 \mathrm{H}, J=9.2 \mathrm{~Hz}), 7.14(\mathrm{~d}, 2 \mathrm{H}, J=8.4 \mathrm{~Hz}), 7.37-7.41(\mathrm{~m}, 4 \mathrm{H}), 7.77-7.81(\mathrm{~m}, 6 \mathrm{H}), 7.98-8.04(\mathrm{~m}, 4 \mathrm{H})$, $8.24(\mathrm{~d}, 4 \mathrm{H}, J=8.2 \mathrm{~Hz}), 8.87(\mathrm{~d}, 4 \mathrm{H}, J=4.2 \mathrm{~Hz}), 8.91(\mathrm{~d}, 4 \mathrm{H}, J=4.2 \mathrm{~Hz}) ;{ }^{13} \mathrm{C}-\mathrm{NMR}\left(100 \mathrm{MHz}, \mathrm{CDCl}_{3}\right)$

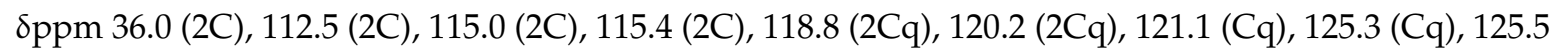
(2Cq), $126.7(4 \mathrm{C}), 127.7(2 \mathrm{C}), 128.2$ (2Cq), $129.0(2 \mathrm{C}), 129.7(4 \mathrm{C}), 130.3(4 \mathrm{C}), 132.9$ (2C), $134.0(2 \mathrm{C}), 134.5$ (4C), 136.8 (4Cq), 142.1 (4Cq), 145.0 (4Cq), 145.1 (4Cq). HRMS-APCI calcd. for: $\mathrm{C}_{58} \mathrm{H}_{39} \mathrm{Br}_{2} \mathrm{~N}_{6} \mathrm{~S}_{2}[\mathrm{M}+$ $\mathrm{H}]^{+}$1043.1018; found: 1043.0968 .

\section{5,15-diphenyl-10,20-bis (2-chloro-10-methyl-10H-phenothiazin-7-yl)-21,23H-porphyrin 3b}

Purification by column chromatography using dichloromethane/petrol ether (2:1) as eluent gave a purple powder; yield 10\% $(0.3 \mathrm{~g}) ;{ }^{1} \mathrm{H}-\mathrm{NMR}\left(400 \mathrm{MHz}, \mathrm{CDCl}_{3}\right) \delta \mathrm{ppm}-2.77(\mathrm{~s}, 2 \mathrm{H}, \mathrm{NH}), 3.65(\mathrm{~s}, 6 \mathrm{H})$, 7.03-7.05 (m, 4H), 7.16-7.21 (m, 4H), 7.76-7.81 (m, 6H), $8.02(\mathrm{~d}, 4 \mathrm{H}, J=7.4 \mathrm{~Hz}), 8.23(\mathrm{~d}, 4 \mathrm{H}, J=8.4 \mathrm{~Hz})$, 8.86-8.90 (m, 8H); ${ }^{13} \mathrm{C}-\mathrm{NMR}\left(100 \mathrm{MHz}, \mathrm{CDCl}_{3}\right) \delta \mathrm{ppm} 35.7$ (2C), 112.6 (2C), $114.8(4 \mathrm{C}), 118.8$ (2Cq), $120.2(2 \mathrm{Cq}), 121.6(\mathrm{Cq}), 121.7(2 \mathrm{Cq}), 122.5(4 \mathrm{C}), 126.7(6 \mathrm{C}), 127.7(4 \mathrm{Cq}), 127.9(4 \mathrm{C}), 128.2(\mathrm{Cq}) 132.9(2 \mathrm{Cq})$, $133.7(3 \mathrm{Cq}), 133.9$ (3Cq), 134.5 (4C), 136.9 (4C), 142.0 (2Cq), 144.8 (2Cq), 147.0 (4Cq). HRMS-APCI calcd. for: $\mathrm{C}_{58} \mathrm{H}_{39} \mathrm{Cl}_{2} \mathrm{~N}_{6} \mathrm{~S}_{2}[\mathrm{M}+\mathrm{H}]^{+}$952.1976; found: 952.1905 .

\subsubsection{General Procedure for the Preparation of Metallo-Phenothiazinyl-Porphyrins}

A solution of phenothiazinyl-porphyrin free base (2) or (3) $(1 \mathrm{mmol})$ and Metal(II)-acetate $(1.1 \mathrm{mmol})$ in DMF (50 mL) was heated to reflux for $6 \mathrm{~h}$. The purification was achieved by column chromatography on silica gel, using chloroform/hexane (1:2) as eluent.

\section{5,10,15-triphenyl-20-(7-bromo-10-methyl-10H-phenothiazin-3-yl)-21,23-Zn-porphyrin $4 a$}

Purple powder; yield 90\% (0.9 g); ${ }^{1} \mathrm{H}-\mathrm{NMR}\left(600 \mathrm{MHz}, \mathrm{CDCl}_{3}\right) \delta \mathrm{ppm} 3.59(\mathrm{~s}, 3 \mathrm{H}), 6.83(\mathrm{~d}, 1 \mathrm{H}, J=$ $8.7 \mathrm{~Hz}), 7.15(\mathrm{~d}, 1 \mathrm{H}, J=8.1 \mathrm{~Hz}), 7.32(\mathrm{~s}, 1 \mathrm{H}), 7.38(\mathrm{~d}, 1 \mathrm{H}, J=8.7 \mathrm{~Hz}), 7.76-7.82(\mathrm{~m}, 9 \mathrm{H}), 7.97(\mathrm{~s}, 1 \mathrm{H})$, $8.02(\mathrm{~d}, 1 \mathrm{H}, J=8.1 \mathrm{~Hz}), 8.26(\mathrm{~d}, 6 \mathrm{H}, J=8.4 \mathrm{~Hz}), 8.97-9.01(\mathrm{~m}, 6 \mathrm{H}), 9.01(\mathrm{~d}, 2 \mathrm{H}, J=4.6 \mathrm{~Hz}) ;{ }^{13} \mathrm{C}-\mathrm{NMR}$ $\left(150 \mathrm{MHz}, \mathrm{CDCl}_{3}\right) \delta \mathrm{ppm} 35.7,112.3,114.9(\mathrm{Cq}), 115.4,119.7(\mathrm{Cq}), 120.9(\mathrm{Cq}), 121.2(2 \mathrm{Cq}), 125.5(\mathrm{Cq})$, 126.5 (6C), $126.6(2 \mathrm{C}), 127.5$ (3C), 129.6, 130.2, 131.8 (2Cq), 132.0 (6C), 132.1 (2C), 132.8, 133.8, 134.43 (2C), 134.45 (2C), $137.4(\mathrm{Cq}), 142.8(4 \mathrm{Cq}), 144.8(\mathrm{Cq}), 145.0(\mathrm{Cq}), 150.2$ (6Cq). HRMS-APCI calcd. for: $\mathrm{C}_{51} \mathrm{H}_{33} \mathrm{BrN}_{5} \mathrm{ZnS}[\mathrm{M}+\mathrm{H}]^{+}$892.0905; found: 892.0872 .

\section{5,10,15-triphenyl-20-(7-bromo-10-methyl-10H-phenothiazin-3-yl)-21,23-Pd-porphyrin $4 b$}

Purple powder; yield 80\% (0.9 g); ${ }^{1} \mathrm{H}-\mathrm{NMR}\left(600 \mathrm{MHz}, \mathrm{CDCl}_{3}\right) \delta \mathrm{ppm} 3.60(\mathrm{~s}, 3 \mathrm{H}), 6.85(\mathrm{~d}, 1 \mathrm{H}, J=$ $8.4 \mathrm{~Hz}), 7.15(\mathrm{~d}, 1 \mathrm{H}, J=8.5 \mathrm{~Hz}), 7.38\left(\mathrm{~s}, 1 \mathrm{H}, \mathrm{H}_{6}\right), 7.40(\mathrm{~d}, 1 \mathrm{H}, J=8.4 \mathrm{~Hz}), 7.74-7.81(\mathrm{~m}, 9 \mathrm{H}), 7.95-7.98$ $(\mathrm{m}, 2 \mathrm{H}), 8.17-8.21(\mathrm{~m}, 6 \mathrm{H}), 8.81-8.85(\mathrm{~m}, 6 \mathrm{H}), 8.89(\mathrm{~d}, 2 \mathrm{H}, J=4.8 \mathrm{~Hz}) ;{ }^{13} \mathrm{C}-\mathrm{NMR}\left(150 \mathrm{MHz}, \mathrm{CDCl}_{3}\right) \delta$ ppm 35.7, $112.3(\mathrm{Cq}), 112.4,114.3(\mathrm{Cq}), 115.0(\mathrm{Cq}), 115.4,120.3(\mathrm{Cq}), 121.2(\mathrm{Cq}), 121.7(2 \mathrm{Cq}), 125.5(\mathrm{Cq})$, $126.71(4 \mathrm{C}), 126.78(2 \mathrm{C}), 127.4(\mathrm{Cq}), 127.7$ (3C), $128.2(\mathrm{Cq}), 129.6,130.3,130.8(2 \mathrm{Cq}), 130.9(2 \mathrm{C}), 131.01$ (6C), 131.04 (2C), 132.5, $133.4(\mathrm{Cq}), 133.5,134.0$ (2C), 134.1 (2C), $136.4(\mathrm{Cq}), 141.6$ (4Cq), 141.7 (2Cq), 145.0 (Cq). HRMS-APCI calcd. for: $\mathrm{C}_{51} \mathrm{H}_{33} \mathrm{BrN}_{5} \mathrm{PdS}[\mathrm{M}+\mathrm{H}]^{+}$934.0648; found: 934.0641 .

\section{5,10,15-triphenyl-20-(7-bromo-10-methyl-10H-phenothiazin-3-yl)-21,23-Ni-porphyrin 4c}

Purple powder; yield 85\% (0.9 g); ${ }^{1} \mathrm{H}-\mathrm{NMR}\left(600 \mathrm{MHz}, \mathrm{CDCl}_{3}\right) \delta \mathrm{ppm} 3.57(\mathrm{~s}, 3 \mathrm{H}), 6.82(\mathrm{~d}, 1 \mathrm{H}, J=$ $8.2 \mathrm{~Hz}), 7.10(\mathrm{~d}, 1 \mathrm{H}, J=7.8 \mathrm{~Hz}), 7.37(\mathrm{~s}, 1 \mathrm{H}), 7.38(\mathrm{~d}, 1 \mathrm{H}, J=8.2 \mathrm{~Hz}), 7.69-7.73(\mathrm{~m}, 9 \mathrm{H}), 7.81(\mathrm{~d}, 1 \mathrm{H}, J=$ 
$7.8 \mathrm{~Hz}), 7.82(\mathrm{~s}, 1 \mathrm{H}), 8.02-8.05(\mathrm{~m}, 6 \mathrm{H}), 8.76-8.78(\mathrm{~m}, 6 \mathrm{H}), 8.80(\mathrm{~d}, 2 \mathrm{H}, J=4.8 \mathrm{~Hz}) ;{ }^{13} \mathrm{C}-\mathrm{NMR}(150 \mathrm{MHz}$, $\left.\mathrm{CDCl}_{3}\right) \delta$ ppm $35.6\left(\mathrm{CH}_{3}\right), 112.6(\mathrm{CH}), 115.0(\mathrm{Cq}), 115.4(\mathrm{CH}), 117.6(\mathrm{Cq}), 119.0(2 \mathrm{Cq}), 121.3(\mathrm{Cq}), 125.5$ $(\mathrm{Cq}), 126.9(6 \mathrm{CH}), 127.7(3 \mathrm{CH}), 129.6(\mathrm{CH}), 130.3(\mathrm{CH}), 132.0(2 \mathrm{CH}), 132.1(\mathrm{CH}), 132.21(4 \mathrm{CH}), 132.23$ $(2 \mathrm{CH}), 133.28(\mathrm{CH}), 133.7(6 \mathrm{CH}), 135.5(\mathrm{Cq}), 140.8(4 \mathrm{Cq}), 142.71(6 \mathrm{Cq}), 142.74(2 \mathrm{Cq}), 145.0(\mathrm{Cq}), 145.1$ (Cq) HRMS-APCI calcd. for: $\mathrm{C}_{51} \mathrm{H}_{33} \mathrm{BrN}_{5} \mathrm{NiS}[\mathrm{M}+\mathrm{H}]^{+}$886.0967; found: 886.0952.

5,10,15-triphenyl-20-(7-bromo-10-methyl-10H-phenothiazin-3-yl)-21,23-Cu-porphyrin 4d

Purple powder; yield 80\% (0.86 g), HRMS-APCI calcd. for: $\mathrm{C}_{51} \mathrm{H}_{33} \mathrm{BrN}_{5} \mathrm{CuS}[\mathrm{M}+\mathrm{H}]^{+}$889.0930; found: 889.0912 .

5,10,15-triphenyl-20-(8-chloro-10-methyl-10H-phenothiazin-3-yl)-21,23-Zn-porphyrin 5a

Purple powder; yield 95\% (1 g); ${ }^{1} \mathrm{H}-\mathrm{NMR}\left(600 \mathrm{MHz}, \mathrm{CDCl}_{3}\right) \delta \mathrm{ppm} 3.62(\mathrm{~s}, 3 \mathrm{H}), 6.97(\mathrm{~s}, 1 \mathrm{H}), 7.00$ $(\mathrm{d}, 1 \mathrm{H}, J=8.4 \mathrm{~Hz}), 7.09(\mathrm{~d}, 1 \mathrm{H}, J=7.9 \mathrm{~Hz}), 7.16(\mathrm{~d}, 1 \mathrm{H}, J=8.4 \mathrm{~Hz}), 7.75-7.82(\mathrm{~m}, 9 \mathrm{H}), 7.97(\mathrm{~s}, 1 \mathrm{H}), 8.02$ $(\mathrm{d}, 1 \mathrm{H}, J=7.9 \mathrm{~Hz}), 8.23-8.25(\mathrm{~m}, 6 \mathrm{H}), 8.96-8.98(\mathrm{~m}, 6 \mathrm{H}), 9.00(\mathrm{~d}, 2 \mathrm{H}, J=4.6 \mathrm{~Hz}) ;{ }^{13} \mathrm{C}-\mathrm{NMR}(150 \mathrm{MHz}$, $\mathrm{CDCl}_{3}$ ) $\delta$ ppm 35.7, 112.4, 114.7, $119.6(\mathrm{Cq}), 121.21(2 \mathrm{Cq}), 121.27(\mathrm{Cq}), 121.3(\mathrm{Cq}), 121.7(\mathrm{Cq}), 122.4$, 126.51 (4C), 126.57 (2C), 127.5 (3C), 127.8, 131.8 (3Cq), 132.01 (4C), 132.04 (2C), 132.8, 133.6 (Cq), 133.7, 134.41 (4C), $134.44(4 \mathrm{C}), 137.6(\mathrm{Cq}), 142.8$ (3Cq), $144.5(\mathrm{Cq}), 147.0(\mathrm{Cq}), 150.2$ (5Cq). HRMS-APCI calcd. for: $\mathrm{C}_{51} \mathrm{H}_{33} \mathrm{ClN}_{5} \mathrm{ZnS}[\mathrm{M}+\mathrm{H}]^{+}$846.1431; found: 846.1419.

\section{5,10,15-triphenyl-20-(8-chloro-10-methyl-10H-phenothiazin-3-yl)-21,23-Pd-porphyrin 5b}

Purple powder; yield 90\% (1 g); ${ }^{1} \mathrm{H}-\mathrm{NMR}\left(400 \mathrm{MHz}, \mathrm{CDCl}_{3}\right) \delta \mathrm{ppm} 3.64\left(\mathrm{~s}, 3 \mathrm{H}, \mathrm{CH}_{3}\right), 7.02-7.08$ $\left(\mathrm{m}, 2 \mathrm{H}, \mathrm{H}_{1,9}\right), 7.15\left(\mathrm{~d}, 1 \mathrm{H},{ }^{3} \mathrm{~J}=8.2 \mathrm{~Hz}, \mathrm{H}_{3}\right), 7.34\left(\mathrm{~d}, 1 \mathrm{H}, J=8.2 \mathrm{~Hz} \mathrm{H}_{8}\right), 7.73-7.79\left(\mathrm{~m}, 9 \mathrm{H}, \mathrm{H}_{\mathrm{b}, \mathrm{c}}\right), 7.95$ $\left(\mathrm{d}, 1 \mathrm{H}, J=8.2 \mathrm{~Hz} \mathrm{H}_{4}\right), 7.98\left(\mathrm{~s}, 1 \mathrm{H}, \mathrm{H}_{6}\right), 8.17-8.20\left(\mathrm{~m}, 6 \mathrm{H}, \mathrm{H}_{\mathrm{a}}\right), 8.82-8.84\left(\mathrm{~m}, 6 \mathrm{H}, \mathrm{H}_{\beta}\right), 8.89\left(\mathrm{~d}, 2 \mathrm{H},{ }^{3} J=\right.$ $\left.4.9 \mathrm{~Hz}, \mathrm{H}_{\beta}\right) ;{ }^{13} \mathrm{C}-\mathrm{NMR}\left(100 \mathrm{MHz}, \mathrm{CDCl}_{3}\right) \delta \mathrm{ppm} 35.6,112.3,114.3,120.7(\mathrm{Cq}), 121.7(2 \mathrm{Cq}), 121.9(\mathrm{Cq})$, $122.8(\mathrm{Cq}), 123.3(\mathrm{Cq}), 126.7(4 \mathrm{C}), 126.7(2 \mathrm{C}), 127.4,127.7,127.7(3 \mathrm{C}), 131.0(4 \mathrm{C}), 131.0(2 \mathrm{C}), 132.5,133.3$, $134.4(4 \mathrm{C}), 134.4(4 \mathrm{C}), 136.0(\mathrm{Cq}), 141.5(4 \mathrm{Cq}), 141.6(2 \mathrm{Cq}), 141.7(2 \mathrm{Cq}), 141.7(4 \mathrm{Cq}), 145.5(\mathrm{Cq}), 145.8$ (Cq). HRMS-APCI calcd. for: $\mathrm{C}_{51} \mathrm{H}_{33} \mathrm{ClN}_{5} \mathrm{PdS}[\mathrm{M}+\mathrm{H}]^{+}$890.1178; found: 890.1147.

5,10,15-triphenyl-20-(8-chloro-10-methyl-10H-phenothiazin-3-yl)-21,23-Ni-porphyrin 5c

Purple powder; yield 88\% (0.94 g); ${ }^{1} \mathrm{H}-\mathrm{NMR}\left(600 \mathrm{MHz}, \mathrm{CDCl}_{3}\right) \delta \mathrm{ppm} 3.58(\mathrm{~s}, 3 \mathrm{H}), 6.96-7.02$ (m, 2H), 7.11-7.13 (m, 2H), 7.68-7.73 (m, 9H), 7.81-7.83 (m, 2H), 8.03-8.07 (d, 6H), 8.78-8.81 (m, 8H); ${ }^{13} \mathrm{C}-\mathrm{NMR}\left(150 \mathrm{MHz}, \mathrm{CDCl}_{3}\right) \delta \mathrm{ppm} 35.6,112.7,114.7,117.6(\mathrm{Cq}), 119.02(\mathrm{Cq}), 119.07,121.7(\mathrm{Cq}), 121.8$ (Cq), 122.5, 126.8 (6C), 127.7 (3C), 127.9, 132.0 (2C), 132.1, 132.24 (4C), 132.29 (2C), 133.1 (2Cq), 133.7 (6C), 135.7 (Cq), 140.9 (4Cq), 142.7 (8Cq), 144.9 (Cq), 146.9 (Cq). HRMS-APCI calcd. for: $\mathrm{C}_{51} \mathrm{H}_{33} \mathrm{ClN}_{5} \mathrm{NiS}$ [M $+\mathrm{H}]^{+}$840.1493; found: 840.1474 .

\section{5,10,15-triphenyl-20-(8-chloro-10-methyl-10H-phenothiazin-3-yl)-21,23-Cu-porphyrin $5 d$}

Purple powder; yield 80\% (0.86 g); HRMS-APCI Calcd. for: $\mathrm{C}_{51} \mathrm{H}_{33} \mathrm{ClN}_{5} \mathrm{CuS}[\mathrm{M}+\mathrm{H}]^{+} 845.1435$; found: 845.1420 .

\section{5,15-diphenyl-10,20-bis(7-bromo-10-methyl-10H-phenothiazin-3-yl)-21,23-Zn-porphyrin $6 a$}

Purple powder; yield 80\% (0.85 g); ${ }^{1} \mathrm{H}-\mathrm{NMR}\left(600 \mathrm{MHz}, \mathrm{CDCl}_{3}\right) \delta \mathrm{ppm} 3.52(\mathrm{~s}, 6 \mathrm{H}), 6.78(\mathrm{~d}, 2 \mathrm{H}, J=$ $8.5 \mathrm{~Hz}), 7.08(\mathrm{~d}, 2 \mathrm{H}, J=8.2 \mathrm{~Hz}), 7.26(\mathrm{~s}, 2 \mathrm{H}), 7.34(\mathrm{~d}, 2 \mathrm{H}, J=8.5 \mathrm{~Hz}), 7.75-7.79(\mathrm{~m}, 6 \mathrm{H}), 7.90-7.98(\mathrm{~m}$, $4 \mathrm{H}), 8.22-8.24(\mathrm{~m}, 4 \mathrm{H}), 8.94-8.96(\mathrm{~m}, 8 \mathrm{H}) ;{ }^{13} \mathrm{C}-\mathrm{NMR}\left(150 \mathrm{MHz}, \mathrm{CDCl}_{3}\right) \delta \mathrm{ppm} 35.6(2 \mathrm{C}), 112.2(2 \mathrm{C})$, $112.3(\mathrm{Cq}), 114.8(2 \mathrm{Cq}), 114.9(\mathrm{Cq}), 115.4(2 \mathrm{C}), 119.6(\mathrm{Cq}), 120.7(\mathrm{Cq}), 120.8(\mathrm{Cq}), 121.14(\mathrm{Cq}), 121.17$ (2Cq), $125.3(\mathrm{Cq}), 125.4(\mathrm{Cq}), 126.53(2 \mathrm{C}), 126.57(2 \mathrm{C}), 127.4(2 \mathrm{C}), 129.5(2 \mathrm{Cq}), 129.6(\mathrm{Cq}), 130.2(2 \mathrm{C})$, $131.8(2 \mathrm{C}), 132.03(2 \mathrm{C}), 132.08(2 \mathrm{C}), 132.8(\mathrm{Cq}), 132.9(\mathrm{Cq}), 133.82(2 \mathrm{Cq}), 133.86(\mathrm{Cq}), 134.5(2 \mathrm{C}), 137.5$ (2C), 142.9 (2C), 144.7 (4Cq), 145.0 (2C), 150.2 (6Cq). HRMS-APCI calcd. for: $\mathrm{C}_{58} \mathrm{H}_{37} \mathrm{Br}_{2} \mathrm{~N}_{6} \mathrm{ZnS}_{2}[\mathrm{M}+$ $\mathrm{H}]^{+}$1105.0153; found: 1105.0118 . 
5,15-diphenyl-10,20-bis(7-bromo-10-methyl-10H-phenothiazin-3-yl)-21,23-Pd-porphyrin 66

Purple powder; yield 80\% (0.88 g); ${ }^{1} \mathrm{H}-\mathrm{NMR}\left(400 \mathrm{MHz}, \mathrm{CDCl}_{3}\right) \delta \mathrm{ppm} 3.54(\mathrm{~s}, 6 \mathrm{H}), 6.81(\mathrm{~d}, 2 \mathrm{H}, J=$ $8.8 \mathrm{~Hz}), 7.01(\mathrm{~d}, 2 \mathrm{H}, J=8.4 \mathrm{~Hz}), 7.20(\mathrm{~d}, 2 \mathrm{H}, J=8.8 \mathrm{~Hz}), 7.36(\mathrm{~s}, 2 \mathrm{H}), 7.74-7.78(\mathrm{~m}, 6 \mathrm{H}), 7.90-7.94(\mathrm{~m}$, $4 \mathrm{H}), 8.18(\mathrm{~d}, 4 \mathrm{H}, J=8.6 \mathrm{~Hz}), 8.81-8.87(\mathrm{~m}, 8 \mathrm{H}) ;{ }^{13} \mathrm{C}-\mathrm{NMR}\left(150 \mathrm{MHz}, \mathrm{CDCl}_{3}\right) \delta \mathrm{ppm} 35.6(2 \mathrm{C}), 112.4$ (2C), $114.4(\mathrm{Cq}), 115.0(2 \mathrm{Cq}), 115.4(2 \mathrm{C}), 120.4(\mathrm{Cq}), 121.9(\mathrm{Cq}), 125.3(\mathrm{Cq}), 125.50(\mathrm{Cq}), 125.54(\mathrm{Cq})$, 1263.7 (6C), 127.8 (2C), 129.0 (2C), $129.7(4 \mathrm{C}), 130.0$ (2C), 130.0 (2C), $130.3(2 \mathrm{C}), 131.0(2 \mathrm{C}), 131.14(2 \mathrm{C})$, $131.19(2 \mathrm{C}), 132.4(2 \mathrm{Cq}), 133.5(\mathrm{Cq}), 134.11(2 \mathrm{Cq}), 134.14(2 \mathrm{Cq}), 136.3(\mathrm{Cq}), 141.61(2 \mathrm{Cq}), 141.67(2 \mathrm{Cq})$, 141.7 (2Cq), 145.07 (2Cq), 145.09 (2Cq). HRMS-APCI calcd. for: $\mathrm{C}_{58} \mathrm{H}_{37} \mathrm{Br}_{2} \mathrm{~N}_{6} \mathrm{PdS}_{2}[\mathrm{M}+\mathrm{H}]^{+} 1146.9871$; found: 1146.9896 .

\section{5,15-diphenyl-10,20-bis(7-bromo-10-methyl-10H-phenothiazin-3-yl)-21,23-Ni-porphyrin 6c}

Purple powder; yield 85\% (0.89 g); ${ }^{1} \mathrm{H}-\mathrm{NMR}\left(600 \mathrm{MHz}, \mathrm{CDCl}_{3}\right) \delta \mathrm{ppm} 3.55(\mathrm{~s}, 6 \mathrm{H}), 6.80(\mathrm{~d}, 2 \mathrm{H}, J=$ $9.2 \mathrm{~Hz}), 7.08(\mathrm{~d}, 2 \mathrm{H}, J=8.0 \mathrm{~Hz}), 7.36-7.37(\mathrm{~m}, 4 \mathrm{H}), 7.68-7.73(\mathrm{~m}, 6 \mathrm{H}), 7.79-7.81(\mathrm{~m}, 4 \mathrm{H}), 8.02(\mathrm{~d}, 4 \mathrm{H}$, $J=8.4 \mathrm{~Hz}), 8.76-8.80(\mathrm{~m}, 8 \mathrm{H}) ;{ }^{13} \mathrm{C}-\mathrm{NMR}\left(150 \mathrm{MHz}, \mathrm{CDCl}_{3}\right) \delta \mathrm{ppm} 35.6(2 \mathrm{C}), 112.6(2 \mathrm{C}), 115.0(2 \mathrm{Cq})$, $115.4(2 \mathrm{C}), 117.7(\mathrm{Cq}), 119.1(\mathrm{Cq}), 121.4(2 \mathrm{Cq}), 125.4(2 \mathrm{Cq}), 126.9(4 \mathrm{C}), 127.8(2 \mathrm{Cq}), 129.6(2 \mathrm{C}), 130.3(2 \mathrm{C})$, 132.0 (2C), 132.1 (4C), 132.2 (2C), 132.3 (2C), 133.2 (2C), 133.7 (6C), $135.5(\mathrm{Cq}), 140.8(\mathrm{Cq}), 142.70$ (5Cq), 142.77 (5Cq), 145.0 (2Cq), 145.1 (2Cq). HRMS-APCI calcd. for: $\mathrm{C}_{58} \mathrm{H}_{37} \mathrm{Br}_{2} \mathrm{~N}_{6} \mathrm{NiS}_{2}[\mathrm{M}+\mathrm{H}]^{+}$1099.0215; found: 1099.0195 .

\section{5,15-diphenyl-10,20-bis(7-bromo-10-methyl-10H-phenothiazin-3-yl)-21,23-Cu-porphyrin $6 d$}

Purple powder; yield 80\% (0.84 g); HRMS-APCI calcd. for: $\mathrm{C}_{58} \mathrm{H}_{37} \mathrm{Br}_{2} \mathrm{~N}_{6} \mathrm{CuS}_{2}[\mathrm{M}+\mathrm{H}]^{+}$1104.0157; found: 1104.0133 .

\section{5,15-diphenyl-10,20-bis(8-chloro-10-methyl-10H-phenothiazin-3-yl)-21,23-Zn-porphyrin 7a}

Purple powder; yield 95\% (1 g); ${ }^{1} \mathrm{H}-\mathrm{NMR}\left(600 \mathrm{MHz}, \mathrm{CDCl}_{3}\right) \delta \mathrm{ppm} 3.59(\mathrm{~s}, 6 \mathrm{H}), 6.95(\mathrm{~s}, 2 \mathrm{H}), 6.99$ $(\mathrm{d}, 2 \mathrm{H}, J=8.4 \mathrm{~Hz}), 7.04(\mathrm{~d}, 2 \mathrm{H}, J=8.2 \mathrm{~Hz}), 7.14(\mathrm{~d}, 2 \mathrm{H}, J=8.4 \mathrm{~Hz}), 7.76-7.81(\mathrm{~m}, 6 \mathrm{H}), 7.91(\mathrm{~d}, 2 \mathrm{H}, J=$ $8.4 \mathrm{~Hz}), 7.99(\mathrm{~d}, 2 \mathrm{H}, J=8.2 \mathrm{~Hz}), 8.22-8.24(\mathrm{~m}, 4 \mathrm{H}), 8.95-8.99(\mathrm{~m}, 8 \mathrm{H}) ;{ }^{13} \mathrm{C}-\mathrm{NMR}\left(150 \mathrm{MHz}, \mathrm{CDCl}_{3}\right) \delta$ ppm $35.6(2 \mathrm{C}), 112.4(2 \mathrm{Cq}), 114.7(4 \mathrm{C}), 119.74(\mathrm{Cq}), 119.78(\mathrm{Cq}), 121.23(\mathrm{Cq}), 121.28(\mathrm{Cq}), 121.53(\mathrm{Cq})$, 121.59 (Cq), $122.4(4 \mathrm{C}), 126.5(4 \mathrm{C}), 127.5(2 \mathrm{C}), 127.8(2 \mathrm{C}), 131.8$ (2C), $131.9(2 \mathrm{C}), 132.0(4 \mathrm{C}), 132.7$ (Cq), 132.8 (Cq), 133.6 (2Cq), 133.7 (2Cq), 134.4 (2C), 137.5 (2Cq), 142.8 (2Cq), 144.4 (2Cq), 146.9 (2Cq), 150.23 (4Cq), 150.27 (4Cq) HRMS-APCI calcd. for: $\mathrm{C}_{58} \mathrm{H}_{37} \mathrm{Cl}_{2} \mathrm{~N}_{6} \mathrm{ZnS}_{2}[\mathrm{M}+\mathrm{H}]^{+}$1017.1154; found: 1017.1118.

\section{5,15-diphenyl-10,20-bis(8-chloro-10-methyl-10H-phenothiazin-3-yl)-21,23-Pd-porphyrin $7 b$}

Purple powder; yield 90\% (1 g); ${ }^{1} \mathrm{H}-\mathrm{NMR}\left(600 \mathrm{MHz}, \mathrm{CDCl}_{3}\right) \delta \mathrm{ppm} 3.65(\mathrm{~s}, 6 \mathrm{H}), 7.00(\mathrm{~s}, 2 \mathrm{H}), 7.04$ $(\mathrm{d}, 2 \mathrm{H}, J=8.4 \mathrm{~Hz}), 7.18-7.21(\mathrm{~m}, 4 \mathrm{H}), 7.75-7.81(\mathrm{~m}, 6 \mathrm{H}), 7.96-7.99(\mathrm{~m}, 4 \mathrm{H}), 8.18(\mathrm{~d}, 4 \mathrm{H}, J=8.6 \mathrm{~Hz})$, 8.82-8.90 (m, 8H); ${ }^{13} \mathrm{C}-\mathrm{NMR}\left(150 \mathrm{MHz}, \mathrm{CDCl}_{3}\right) \delta$ ppm 35.6 (2C), 112.6 (2Cq), 114.7 (4C), 119.72, 119.77, $121.2(2 \mathrm{Cq}), 121.50(\mathrm{Cq}), 121.53(\mathrm{Cq}), 122.5(4 \mathrm{C}), 126.7(4 \mathrm{C}), 127.5(2 \mathrm{C}), 127.8(2 \mathrm{C}), 131.8(2 \mathrm{C}), 131.9$ (2C), $132.0(2 \mathrm{C}), 132.7(\mathrm{Cq}), 132.8(\mathrm{Cq}), 133.6(2 \mathrm{Cq}), 133.7$ (2Cq), $134.7(4 \mathrm{C}), 137.5(2 \mathrm{Cq}), 142.8(2 \mathrm{Cq})$, $144.4(2 \mathrm{Cq}), 146.9$ (2Cq), 150.2 (4Cq), 150.2 (4Cq). HRMS-APCI calcd. for: $\mathrm{C}_{58} \mathrm{H}_{37} \mathrm{Cl}_{2} \mathrm{~N}_{6} \mathrm{PdS}_{2}[\mathrm{M}+\mathrm{H}]^{+}$ 1059.0931; found: 1059.0891 .

\section{5,15-diphenyl-10,20-bis(8-chloro-10-methyl-10H-phenothiazin-3-yl)-21,23-Ni-porphyrin 7c}

Ni-2j Purple powder; yield 85\% (0.9 g); ${ }^{1} \mathrm{H}-\mathrm{NMR}\left(600 \mathrm{MHz}, \mathrm{CDCl}_{3}\right) \delta \mathrm{ppm} 3.53$ (s, 6H), 6.93 (s, $2 \mathrm{H}), 6.98(\mathrm{~d}, 2 \mathrm{H}, J=8.6 \mathrm{~Hz}), 7.05(\mathrm{~d}, 2 \mathrm{H}, J=8.2 \mathrm{~Hz}), 7.10(\mathrm{~d}, 2 \mathrm{H}, J=8.6 \mathrm{~Hz}), 7.68-7.72(\mathrm{~m}, 6 \mathrm{H}), 7.78(\mathrm{~d}$, $2 \mathrm{H}, J=8.2 \mathrm{~Hz}), 7.82(\mathrm{~s}, 2 \mathrm{H}), 8.04(\mathrm{~d}, 4 \mathrm{H}), 8.77-8.81(\mathrm{~m}, 8 \mathrm{H},) ;{ }^{13} \mathrm{C}-\mathrm{NMR}\left(150 \mathrm{MHz}, \mathrm{CDCl}_{3}\right) \delta \mathrm{ppm} 35.6$ (2C), $112.6(2 \mathrm{Cq}), 114.7(2 \mathrm{C}), 119.70,119.75,121.2(2 \mathrm{Cq}), 121.50(\mathrm{Cq}), 121.53(\mathrm{Cq}), 122.7(4 \mathrm{C}), 126.8(4 \mathrm{C})$, $127.3(2 \mathrm{C}), 127.9(2 \mathrm{C}), 130.7(2 \mathrm{C}), 131.4(2 \mathrm{C}), 132.5(2 \mathrm{C}), 132.9(2 \mathrm{Cq}), 133.1(2 \mathrm{Cq}), 133.5(2 \mathrm{Cq}), 133.6(2 \mathrm{Cq})$, 134.7 (4C), 137.6 (2Cq), 142.9 (2Cq), $144.4(2 \mathrm{Cq}), 146.9$ (2Cq), 150.3 (4Cq), 150.4 (4Cq). HRMS-APCI calcd. for: $\mathrm{C}_{58} \mathrm{H}_{37} \mathrm{Cl}_{2} \mathrm{~N}_{6} \mathrm{NiS}_{2}[\mathrm{M}+\mathrm{H}]^{+}$1009.1246; found: 1009.1214 . 


\section{5,15-diphenyl-10,20-bis(8-chloro-10-methyl-10H-phenothiazin-3-yl)-21,23-Cu-porphyrin 7d}

Purple powder; yield 80\% (0.85 g); HRMS-APCI calcd. for: $\mathrm{C}_{58} \mathrm{H}_{37} \mathrm{Cl}_{2} \mathrm{~N}_{6} \mathrm{CuS}_{2}[\mathrm{M}+\mathrm{H}]^{+} 1014.1188$; found: 1014.1163 .

\subsubsection{General Procedure for the Synthesis of Suzuki Cross-Coupling Products}

A degassed solution of halogenoMPP porphyrin $2 \mathrm{a}$, 3a or $4 \mathrm{a}(0.12 \mathrm{mmol} 1$ eq $)$, aryl-boronic pinacolate ester $(0.13 \mathrm{mmol}, 1.1 \mathrm{eq}), \mathrm{Pd}\left(\mathrm{PPh}_{3}\right)_{2} \mathrm{Cl}_{2}(0.006 \mathrm{mmol} 0.05 \mathrm{eq}), \mathrm{K}_{2} \mathrm{CO}_{3}(0.1 \mathrm{mmol})$ in DME $(30 \mathrm{~mL})$ and water (15), was heated to reflux under argon atmosphere for $18 \mathrm{~h}$. After cooling to room temperature, the obtained precipitate was filtered off and washed with water. The purification of cross-coupling product was achieved by column chromatography on silica gel using DCM or chloroform as eluent.

\section{5,10,15-triphenyl-20-[7-(10'-methyl-10'H-phenothiazine)-10-methyl-10H-phenothiazin-3-yl]- 21,23H-porphyrin 8}

By starting with $0.15 \mathrm{~g} 2 \mathrm{a}$, purification of the reaction product by column chromatography using DCM eluent gave: purple powder; yield 50\% $(0.07 \mathrm{~g}) ;{ }^{1} \mathrm{H}-\mathrm{NMR}\left(400 \mathrm{MHz}, \mathrm{CDCl}_{3}\right) \delta \mathrm{ppm}-2.76(\mathrm{~s}, 2 \mathrm{H}$, $\mathrm{NH}), 3.64(\mathrm{~s}, 6 \mathrm{H}), 6.87(\mathrm{~d}, 1 \mathrm{H}, J=8.3 \mathrm{~Hz}), 7.19(\mathrm{~d}, 1 \mathrm{H}, J=7.9 \mathrm{~Hz}), 7.39-7.42(\mathrm{~m}, 3 \mathrm{H}), 7.69-7.80(\mathrm{~m}, 12 \mathrm{H})$, $7.89(\mathrm{~d}, 1 \mathrm{H}, J=8.2 \mathrm{~Hz}), 8.02(\mathrm{~s}, 1 \mathrm{H}), 8.04(\mathrm{~d}, 1 \mathrm{H}, J=7.9 \mathrm{~Hz}), 8.12(\mathrm{~d}, 1 \mathrm{H}, J=7.6 \mathrm{~Hz}), 8.19(\mathrm{~d}, 1 \mathrm{H}, J=$ $7.6 \mathrm{~Hz}), 8.21-8.25(\mathrm{~m}, 6 \mathrm{H}), 8.86-8.88(\mathrm{~m}, 6 \mathrm{H}), 8.91(\mathrm{~d}, 2 \mathrm{H}, J=4.7 \mathrm{~Hz}) ;{ }^{13} \mathrm{C}-\mathrm{NMR}\left(100 \mathrm{MHz}, \mathrm{CDCl}_{3}\right) \delta$ ppm 35.3, 36.8, 112.2 (Cq), 113.7, 114.0, $114.2(2 \mathrm{C}), 115.4(\mathrm{Cq}), 118.8(\mathrm{Cq}), 121.15(\mathrm{Cq}), 121.19(2 \mathrm{Cq})$, 122.5, 122.7, $123.0(\mathrm{Cq}), 123.8(\mathrm{Cq}), 124.9(2 \mathrm{C}), 125.4(2 \mathrm{C}), 126.4(4 \mathrm{C}), 126.5,127.2(2 \mathrm{C}), 127.4(2 \mathrm{C}), 127.5$ (2C), $129.6(\mathrm{Cq}), 131.8(\mathrm{Cq}), 131.9(6 \mathrm{C}), 132.8(\mathrm{Cq}), 134.41(6 \mathrm{C}), 134.48(3 \mathrm{C}), 137.6(\mathrm{Cq}), 140.5(\mathrm{Cq}), 142.9$ (2Cq), 144.7 (4Cq), 145.1 (2Cq), 145.6 (2Cq), 148.6 (4Cq). HRMS-APCI calcd. for: $\mathrm{C}_{64} \mathrm{H}_{45} \mathrm{~N}_{6} \mathrm{~S}_{2}[\mathrm{M}+\mathrm{H}]^{+}$ 961.3068; found: 961.1229 .

\section{5,10,15-triphenyl-20-(7-(10'-methyl-10'H-phenothiazine)-10-methyl-10H-phenothiazin-3-yl)- 21,23-Zn-porphyrin 8 a}

By starting with $0.15 \mathrm{~g} 4 \mathrm{a}$, purification of the reaction product by column chromatography using DCM eluent gave: purple powder; yield $55 \%(0.09 \mathrm{~g}) ;{ }^{1} \mathrm{H}-\mathrm{NMR}\left(400 \mathrm{MHz}, \mathrm{CDCl}_{3}\right) \delta \mathrm{ppm} 3.39(\mathrm{~s}, 3 \mathrm{H})$, $3.60(\mathrm{~s}, 3 \mathrm{H}), 6.81-6.86(\mathrm{~m}, 3 \mathrm{H}), 6.93(\mathrm{t}, 1 \mathrm{H}, J=7.4 \mathrm{~Hz}), 7.13(\mathrm{~s}, 1 \mathrm{H}), 7.17-7.21(\mathrm{~m}, 2 \mathrm{H}), 7.29(\mathrm{~d}, 1 \mathrm{H}, J=7.4$ $\mathrm{Hz}), 7.31(\mathrm{~s}, 1 \mathrm{H}), 7.34(\mathrm{~d}, 1 \mathrm{H}, J=7.6 \mathrm{~Hz}), 7.38(\mathrm{~d}, 1 \mathrm{H}, J=7.4 \mathrm{~Hz}), 7.76-7.80(\mathrm{~m}, 9 \mathrm{H}), 7.98(\mathrm{~s}, 1 \mathrm{H}), 8.01(\mathrm{~d}$, $1 \mathrm{H}, J=7.8 \mathrm{~Hz}), 8.25(\mathrm{~d}, 6 \mathrm{H}), 8.99(\mathrm{~d}, 6 \mathrm{H}), 9.00(\mathrm{~d}, 1 \mathrm{H}, J=4.5 \mathrm{~Hz}), 9.03(\mathrm{~d}, 1 \mathrm{H}, J=4.5 \mathrm{~Hz}) ;{ }^{13} \mathrm{C}-\mathrm{NMR}$ $\left(100 \mathrm{MHz}, \mathrm{CDCl}_{3}\right) \delta \mathrm{ppm} 35.3,40.2,112.2(\mathrm{Cq}), 114.0(2 \mathrm{C}), 114.2(2 \mathrm{C}), 115.4(\mathrm{Cq}), 118.8(\mathrm{Cq}), 121.11$ $(\mathrm{Cq}), 121.14(2 \mathrm{Cq}), 122.5(2 \mathrm{C}), 123.0(\mathrm{Cq}), 123.8(\mathrm{Cq}), 124.9(2 \mathrm{C}), 125.4(2 \mathrm{C}), 126.4(4 \mathrm{C}), 126.5,127.2(2 \mathrm{C})$, $127.4(2 \mathrm{C}), 127.5(2 \mathrm{C}), 129.6(\mathrm{Cq}), 131.8(\mathrm{Cq}), 131.9(6 \mathrm{C}), 132.8(\mathrm{Cq}), 134.4(4 \mathrm{C}), 134.4(3 \mathrm{C}), 137.6(\mathrm{Cq})$, $142.9(2 \mathrm{Cq}), 144.7(\mathrm{Cq}), 145.1(\mathrm{Cq}), 145.6(2 \mathrm{Cq}), 150.2$ (8Cq). HRMS-APCI calcd. for: $\mathrm{C}_{64} \mathrm{H}_{42} \mathrm{~N}_{6} \mathrm{~S}_{2} \mathrm{Zn}$ $[\mathrm{M}+\mathrm{H}]^{+}$1022.2203; found: 1022.1968.

\section{5,10,15-triphenyl-20-(7-(3'-formyl-10'-methyl-10H-phenothiazine)-10-methyl-10H-phenothiazin-3-yl)- 21,23H-porphyrin 9}

When starting with $0.1 \mathrm{~g} 2 \mathrm{a}$, purification of the reaction product by column chromatography with DCM gave a purple powder; yield $60 \%(0.07 \mathrm{~g}) ;{ }^{1} \mathrm{H}-\mathrm{NMR}\left(600 \mathrm{MHz}, \mathrm{CDCl}_{3}\right) \delta \mathrm{ppm}-2.76(\mathrm{~s}, 2 \mathrm{H}, \mathrm{NH})$, $3.49(\mathrm{~s}, 3 \mathrm{H}), 3.60(\mathrm{~s}, 3 \mathrm{H}), 6.88-6.91(\mathrm{~m}, 4 \mathrm{H}), 7.06-7.10(\mathrm{~m}, 4 \mathrm{H}), 7.63-7.66(\mathrm{~m}, 2 \mathrm{H}), 7.76-7.79(\mathrm{~m}, 9 \mathrm{H})$, 8.02-8.05 (m, 2H), $8.24(\mathrm{~d}, 6 \mathrm{H}, J=7.8 \mathrm{~Hz}), 8.87-8.93(\mathrm{~m}, 8 \mathrm{H}), 9.83(\mathrm{~s}, 1 \mathrm{H}, \mathrm{CHO}) ;{ }^{13} \mathrm{C}-\mathrm{NMR}(150 \mathrm{MHz}$, $\left.\mathrm{CDCl}_{3}\right) \delta$ ppm 35.6, 35.8, 112.4, $113.6(2 \mathrm{C}), 114.5,115.0(2 \mathrm{C}), 119.0(2 \mathrm{Cq}), 120.2,121.50(\mathrm{Cq}), 121.53$ (Cq), 123.0, 123.6 (2Cq), 123.8 (2Cq), $125.0(3 \mathrm{C}), 125.2(2 \mathrm{C}), 125.7$ (6C), $126.7(4 \mathrm{C}), 127.7,127.9,130.5$ (2C), $131.1(2 \mathrm{C}), 133.0,(2 \mathrm{Cq}) 133.9$ (2Cq), 134.2, 134.5 (4C), 135.5 (2Cq), 136.6, $142.1(4 \mathrm{Cq}), 143.0(2 \mathrm{Cq})$, 145.0 (2Cq), 145.2 (3Cq), 150.7 (2Cq), 190.0 (CHO); HRMS (APCI) calcd. for: $\mathrm{C}_{65} \mathrm{H}_{45} \mathrm{~N}_{6} \mathrm{OS}_{2}\left[\mathrm{M}+\mathrm{H}^{+}\right]$ 989.3018; found: 989.3071 . 
When starting with $0.15 \mathrm{~g} 2 \mathrm{a}$, purification of the reaction product by column chromatography with chloroform/petrol ether 1:1 eluent gave: purple powder; yield $70 \%(0.12 \mathrm{~g}) ;{ }^{1} \mathrm{H}-\mathrm{NMR}(400 \mathrm{MHz}$, $\left.\mathrm{CDCl}_{3}\right) \delta \mathrm{ppm}-2.75(\mathrm{~s}, 2 \mathrm{H}, \mathrm{NH}), 3.72(\mathrm{~s}, 3 \mathrm{H}), 7.13(\mathrm{~d}, 1 \mathrm{H}, J=8.7 \mathrm{~Hz}), 7.21-7.23(\mathrm{~m}, 1 \mathrm{H}), 7.31-7.35(\mathrm{~m}$, $3 \mathrm{H}), 7.44-7.47(\mathrm{~m}, 3 \mathrm{H}, \mathrm{H}), 7.51(\mathrm{~d}, 2 \mathrm{H}, J=8.1 \mathrm{~Hz}), 7.61(\mathrm{~m}, 2 \mathrm{H}), 7.65(\mathrm{~d}, 2 \mathrm{H}, J=8.1 \mathrm{~Hz}), 7.72-7.80(\mathrm{~m}$, $9 \mathrm{H}), 8.03(\mathrm{~d}, 1 \mathrm{H}, J=8.0 \mathrm{~Hz}), 8.07(\mathrm{~s}, 1 \mathrm{H}), 8.18(\mathrm{~d}, 2 \mathrm{H}, J=7.7 \mathrm{~Hz}), 8.24(\mathrm{~d}, 6 \mathrm{H}, J=7.5 \mathrm{~Hz}), 8.87(\mathrm{~s}, 6 \mathrm{H})$, $8.95\left(\mathrm{~d}, 2 \mathrm{H},{ }^{3} \mathrm{~J}=4.4 \mathrm{~Hz}\right) ;{ }^{13} \mathrm{C}-\mathrm{NMR}\left(100 \mathrm{MHz}, \mathrm{CDCl}_{3}\right) \delta \mathrm{ppm} 35.8,109.8(2 \mathrm{C}), 112.4(2 \mathrm{Cq}), 114.7(2 \mathrm{Cq})$, 118.9 (2Cq), 119.9 (2C), 120.2, 121.5, $123.4(2 \mathrm{C}), 125.9$ (6C), 126.7 (9C), $127.4(4 \mathrm{C}), 127.7(2 \mathrm{C}), 127.9(4 \mathrm{C})$, $133.0(2 \mathrm{Cq}), 134.0(2 \mathrm{Cq}), 134.5(8 \mathrm{C}), 135.0(2 \mathrm{Cq}), 136.6(2 \mathrm{Cq}), 136.7(2 \mathrm{Cq}), 140.8(4 \mathrm{Cq}), 142.1(4 \mathrm{Cq}), 145.2$ (Cq), 145.4 (2Cq); HRMS (APCI) calcd. for: $\mathrm{C}_{69} \mathrm{H}_{47} \mathrm{~N}_{6} \mathrm{~S}$ [M + $\mathrm{H}^{+}$] 991.3577; found: 991.3573.

5,10,15-triphenyl-20-(7-phenyl-10-methyl-10H-phenothiazin-3-yl)-21,23H-porphyrin 11

By starting with $0.1 \mathrm{~g} 2 \mathrm{a}$, purification of the reaction product by column chromatography using DCM eluent gave: purple powder; yield $60 \%(0.06 \mathrm{~g}) ;{ }^{1} \mathrm{H}-\mathrm{NMR}\left(400 \mathrm{MHz}, \mathrm{CDCl}_{3}\right) \delta \mathrm{ppm}-2.77(\mathrm{~s}, 2 \mathrm{H}$, $\mathrm{NH}), 3.65(\mathrm{~s}, 3 \mathrm{H}), 7.04(\mathrm{~d}, 1 \mathrm{H}, J=8.5 \mathrm{~Hz}), 7.16(\mathrm{~d}, 1 \mathrm{H}, J=8.1 \mathrm{~Hz}), 7.30-7.33(\mathrm{~m}, 1 \mathrm{H}, \mathrm{H}), 7.42(\mathrm{t}, 2 \mathrm{H}, J=$ $7.4 \mathrm{~Hz}, J=7.7 \mathrm{~Hz}), 7.50(\mathrm{~d}, 2 \mathrm{H}, J=7.6 \mathrm{~Hz}), 7.57(\mathrm{~d}, 2 \mathrm{H}, J=7.4 \mathrm{~Hz}), 7.72-7.75(\mathrm{~m}, 9 \mathrm{H}), 7.99(\mathrm{~d}, 1 \mathrm{H}, J=$ $8.1 \mathrm{~Hz}), 8.02(\mathrm{~s}, 1 \mathrm{H}), 8.20(\mathrm{~d}, 6 \mathrm{H}, J=6.3 \mathrm{~Hz}), 8.83(\mathrm{~s}, 6 \mathrm{H}), 8.90\left(\mathrm{~d}, 2 \mathrm{H},{ }^{3} \mathrm{~J}=4.5 \mathrm{~Hz}\right) ;{ }^{13} \mathrm{C}-\mathrm{NMR}(100 \mathrm{MHz}$, $\left.\mathrm{CDCl}_{3}\right) \delta$ ppm 35.9, 112.5, 114.8, $118.8(\mathrm{Cq}), 120.2(2 \mathrm{Cq}), 121.4(\mathrm{Cq}), 124.1(\mathrm{Cq}), 126.0,126.7(6 \mathrm{C}), 126.9$ (4C), 127.6, 127.7 (3C), 129.6 (Cq), 129.7 (7C), 130.3 (Cq), 130.3 (4C), 131.0 (Cq), 133.0, 133.7 (Cq), 134.0, $134.1(\mathrm{Cq}), 134.2(\mathrm{Cq}), 134.5(4 \mathrm{C}), 134.9(\mathrm{Cq}), 136.9(\mathrm{Cq}), 142.1(4 \mathrm{Cq}), 144.9(\mathrm{Cq}), 145.8(\mathrm{Cq}), 146.1(\mathrm{Cq})$, 150.2 (Cq), $165.4(\mathrm{Cq})$; HRMS (APCI) calcd. for: $\mathrm{C}_{57} \mathrm{H}_{40} \mathrm{~N}_{5} \mathrm{~S}\left[\mathrm{M}+\mathrm{H}^{+}\right]$826.8334; found: 826.8308 .

\section{5,10,15-triphenyl-20-(7-phenyl-10-methyl-10H-phenothiazin-3-yl)-21,23-Zn-porphyrin 11a}

By starting with $0.15 \mathrm{~g} 4 \mathrm{a}$, purification of the reaction product by column chromatography using DCM eluent gave a purple powder; yield $66 \%(0.1 \mathrm{~g}) ;{ }^{1} \mathrm{H}-\mathrm{NMR}\left(600 \mathrm{MHz}, \mathrm{CDCl}_{3}\right) \delta \mathrm{ppm} 3.37(\mathrm{~s}, 3 \mathrm{H})$, $6.87(\mathrm{~d}, 1 \mathrm{H}, J=8.7 \mathrm{~Hz}), 7.10(\mathrm{~d}, 1 \mathrm{H}, J=8.5 \mathrm{~Hz}), 7.21(\mathrm{~d}, 1 \mathrm{H}, J=8.1 \mathrm{~Hz}), 7.36-7.37(\mathrm{~m}, 1 \mathrm{H}), 7.41(\mathrm{~d}, 1 \mathrm{H}, J$ $=8.6 \mathrm{~Hz}), 7.46(\mathrm{t}, 1 \mathrm{H}, J=7.3 \mathrm{~Hz}, J=8.0 \mathrm{~Hz}), 7.51(\mathrm{~s}, 1 \mathrm{H}), 7.55(\mathrm{~d}, 1 \mathrm{H}, J=6.4 \mathrm{~Hz}), 7.61(\mathrm{~d}, 1 \mathrm{H}, J=7.4 \mathrm{~Hz})$, 7.76-7.80 (m, 9H), 8.03-8.04 (m, 2H), 8.24-8.25 (m, 6H), $8.97\left(\mathrm{~s}, 6 \mathrm{H}, \mathrm{H}_{\beta}\right), 9.01(\mathrm{~d}, 1 \mathrm{H}, J=4.5 \mathrm{~Hz}), 9.04(\mathrm{~d}$, $1 \mathrm{H}, J=4.5 \mathrm{~Hz}) ;{ }^{13} \mathrm{C}-\mathrm{NMR}\left(150 \mathrm{MHz}, \mathrm{CDCl}_{3}\right) \delta \mathrm{ppm} 37.6,112.9,115.8,119.8(\mathrm{Cq}), 120.8(2 \mathrm{Cq}), 121.4$ (Cq), 123.7, 124.1 (Cq), $126.4(6 \mathrm{C}), 126.6$ (4C), 128.2, 128.7 (3C), 129.6 (Cq), 129.7 (7C), 130.5 (Cq), 131.9 (4C), 132.0, $133.7(\mathrm{Cq}), 133.8(\mathrm{Cq}), 134.0,134.1(\mathrm{Cq}), 134.3(\mathrm{Cq}), 134.4(4 \mathrm{C}), 137.3(\mathrm{Cq}), 139.2(\mathrm{Cq}), 142.8$ (Cq), $145.5(\mathrm{Cq}), 146.4(\mathrm{Cq}), 148.8(\mathrm{Cq}), 150.2(\mathrm{Cq}), 150.4(2 \mathrm{Cq}), 150.7(\mathrm{Cq}), 156.6(\mathrm{Cq}) ;$ HRMS (APCI) calcd. for: $\mathrm{C}_{57} \mathrm{H}_{38} \mathrm{~N}_{5} \mathrm{SZn}\left[\mathrm{M}+\mathrm{H}^{+}\right]$888.2134; found: 888.2108.

\section{5,10,15-triphenyl-20-(7-(4-formyl-phenyl)-10-methyl-10H-phenothiazin-3-yl)-21,23H-porphyrin 12}

By starting with $0.15 \mathrm{~g} 2 \mathrm{a}$, purification of the reaction product by column chromatography using DCM eluent gave: purple powder; yield $40 \%(0.04 \mathrm{~g}) ;{ }^{1} \mathrm{H}-\mathrm{NMR}\left(600 \mathrm{MHz}, \mathrm{CDCl}_{3}\right) \delta \mathrm{ppm}-2.74(\mathrm{~s}, 2 \mathrm{H}$, $\mathrm{NH}), 3.71(\mathrm{~s}, 3 \mathrm{H}), 7.09(\mathrm{~d}, 1 \mathrm{H}, J=8.4 \mathrm{~Hz}), 7.22(\mathrm{~d}, 1 \mathrm{H}, J=7.8 \mathrm{~Hz}), 7.57-7.59(\mathrm{~m}, 2 \mathrm{H}), 7.78-7.81(\mathrm{~m}, 9 \mathrm{H})$, $7.95(\mathrm{~d}, 2 \mathrm{H}, J=7.9 \mathrm{~Hz}), 8.04-8.06(\mathrm{~m}, 2 \mathrm{H}), 8.19(\mathrm{~s}, 1 \mathrm{H}), 8.24(\mathrm{~d}, 6 \mathrm{H}, J=6.4 \mathrm{~Hz}), 8.83(\mathrm{~d}, 1 \mathrm{H}, J=6.3 \mathrm{~Hz})$, 8.87-8.93 (m, 8H), $10.06(\mathrm{~s}, 1 \mathrm{H}, \mathrm{CHO}) ;{ }^{13} \mathrm{C}-\mathrm{NMR}\left(150 \mathrm{MHz}, \mathrm{CDCl}_{3}\right) \delta \mathrm{ppm} 35.8,112.5,114.6,118.8(\mathrm{Cq})$, $120.2(2 \mathrm{Cq}), 121.4(\mathrm{Cq}), 124.1(\mathrm{Cq}), 126.0,126.7(6 \mathrm{C}), 126.9(4 \mathrm{C}), 127.7(3 \mathrm{C}), 129.6(\mathrm{Cq}), 130.3(\mathrm{Cq}), 129.7$ (7C), $130.3(4 \mathrm{C}), 131.0(\mathrm{Cq}), 133.0,133.7(\mathrm{Cq}), 134.0,134.1(\mathrm{Cq}), 134.2(\mathrm{Cq}), 134.5(4 \mathrm{C}), 134.9(\mathrm{Cq}), 136.9$ (Cq), 142.1 (4Cq), 144.9 (Cq), $145.8(\mathrm{Cq}), 146.1$ (Cq), $150.2(\mathrm{Cq}), 165.4$ (2Cq), 191.8 (CHO); HRMS (APCI) calcd. for: $\mathrm{C}_{58} \mathrm{H}_{40} \mathrm{~N}_{5} \mathrm{OS}\left[\mathrm{M}+\mathrm{H}^{+}\right]$854.2948; found: 854.2949.

5,15-diphenyl-15,20-bis(7-(3'-formyl-10'-methyl-10'H-phenothiazin-7yl)-10-methyl-10H-phenothiazin-3-yl)21,23H-porphyrin 13

After starting with $0.1 \mathrm{~g} 3 \mathrm{a}$, purification of the reaction product by column chromatography with DCM gave 13 as a purple powder; yield $65 \%(0.1 \mathrm{~g}) ;{ }^{1} \mathrm{H}-\mathrm{NMR}\left(400 \mathrm{MHz}, \mathrm{CDCl}_{3}\right) \delta \mathrm{ppm}-2.75(\mathrm{~s}, 2 \mathrm{H}$, $\mathrm{NH}), 3.43(\mathrm{~s}, 6 \mathrm{H}), 3.65(\mathrm{~s}, 6 \mathrm{H}), 6.85(\mathrm{~s}, 4 \mathrm{H}), 7.03(\mathrm{~d} .2 \mathrm{H}, J=6.2 \mathrm{~Hz}), 7.18(\mathrm{~d}, 2 \mathrm{H}, J=8.0 \mathrm{~Hz}), 7.37-7.39(\mathrm{~m}$, 
$4 \mathrm{H}), 7.45(\mathrm{~s}, 4 \mathrm{H}), 7.63-7.66(\mathrm{~m}, 4 \mathrm{H}), 7.77-7.79(\mathrm{~m}, 6 \mathrm{H}), 8.01\left(\mathrm{~d}, 2 \mathrm{H},{ }^{3} \mathrm{~J}=8.0 \mathrm{~Hz}\right), 8.04(\mathrm{~s}, 2 \mathrm{H}), 8.23(\mathrm{~d}, 4 \mathrm{H}$, $J=6.2 \mathrm{~Hz}), 8.87-8.92(\mathrm{~m}, 8 \mathrm{H}), 9.81(\mathrm{~s}, 2 \mathrm{H}, \mathrm{CHO}) ;{ }^{13} \mathrm{C}-\mathrm{NMR}\left(100 \mathrm{MHz}, \mathrm{CDCl}_{3}\right) \delta \mathrm{ppm} 35.7(2 \mathrm{C}), 35.8$ (2C), $112.4(2 \mathrm{Cq}), 113.7(4 \mathrm{C}), 114.6(2 \mathrm{Cq}), 115.0(4 \mathrm{C}), 119.0(2 \mathrm{Cq}), 120.2(2 \mathrm{Cq}), 121.5(\mathrm{Cq}), 123.0(4 \mathrm{C})$, $123.6(2 \mathrm{Cq}), 123.9(\mathrm{Cq}), 125.1(4 \mathrm{C}), 125.3(2 \mathrm{Cq}), 125.7(6 \mathrm{C}), 126.7(4 \mathrm{C}), 127.7(2 \mathrm{C}), 128.0(2 \mathrm{C}), 130.5(2 \mathrm{Cq})$, $131.1(4 \mathrm{C}), 133.0(\mathrm{Cq}), 134.0(\mathrm{Cq}), 134.3(2 \mathrm{Cq}), 134.6(4 \mathrm{C}), 135.5(2 \mathrm{C}), 136.6(2 \mathrm{C}), 142.1(4 \mathrm{Cq}), 143.0(4 \mathrm{Cq})$, 145.0 (4Cq), 145.2 (2Cq), 150.8 (4Cq), 190.1 (2CHO); HRMS (APCI) calcd. for: $\mathrm{C}_{86} \mathrm{H}_{59} \mathrm{~N}_{8} \mathrm{O}_{2} \mathrm{~S}_{4}\left[\mathrm{M}+\mathrm{H}^{+}\right]$ 1363.3638; found: 1363.3625 .

5,15-diphenyl-15,20-bis [7-(4-(9H-carbazole-9-yl)phenyl)-10-methyl-10H-phenothiazin-3-yl)]- 21,23Hporphyrin 14

By starting with $0.1 \mathrm{~g} 3 \mathrm{a}$, purification of the reaction product by column chromatography with chloroform/petrol ether 1:1 eluent gave a purple powder; yield $70 \%(0.1 \mathrm{~g}) ;{ }^{1} \mathrm{H}-\mathrm{NMR}\left(600 \mathrm{MHz}, \mathrm{CDCl}_{3}\right)$ $\delta$ ppm -2.72 (s, 2H, NH), $3.72(\mathrm{~s}, 6 \mathrm{H}), 7.12(\mathrm{~d}, 2 \mathrm{H}, J=9.0 \mathrm{~Hz}), 7.22(\mathrm{~d}, 2 \mathrm{H}, J=8.1 \mathrm{~Hz}), 7.33(\mathrm{t}, 4 \mathrm{H}, J=7.4$ $\mathrm{Hz}, J=7.2 \mathrm{~Hz}), 7.46(\mathrm{t}, 4 \mathrm{H}, J=7.9 \mathrm{~Hz}, J=7.2 \mathrm{~Hz}), 7.50-7.52(\mathrm{~m}, 4 \mathrm{H}), 7.61-7.62(\mathrm{~m}, 2 \mathrm{H}), 7.62(\mathrm{~s}, 2 \mathrm{H}), 7.66$ $(\mathrm{d}, 4 \mathrm{H}, J=8.3 \mathrm{~Hz}), 7.78-7.83(\mathrm{~m}, 10 \mathrm{H}), 8.05(\mathrm{~s}, 2 \mathrm{H}), 8.09(\mathrm{~s}, 2 \mathrm{H}), 8.10(\mathrm{~d}, 4 \mathrm{H}, J=7.6 \mathrm{~Hz}), 8.25(\mathrm{~s}, 4 \mathrm{H})$, 8.88-8.96 (m, 8H); ${ }^{13} \mathrm{C}-\mathrm{NMR}\left(150 \mathrm{MHz}, \mathrm{CDCl}_{3}\right) \delta \mathrm{ppm} 35.7(2 \mathrm{C}), 109.8$ (6C), $112.4(2 \mathrm{Cq}), 114.7(2 \mathrm{C})$, $119.0(\mathrm{Cq}), 119.9(2 \mathrm{Cq}), 120.0(4 \mathrm{C}), 120.2(2 \mathrm{Cq}), 120.3(4 \mathrm{C}), 121.5(\mathrm{Cq}), 123.4(6 \mathrm{C}), 124.0(2 \mathrm{Cq}), 125.9(2 \mathrm{C})$, $125.9(6 \mathrm{C}), 126.4(2 \mathrm{Cq}), 126.7(2 \mathrm{C}), 126.7(2 \mathrm{C}), 127.4(8 \mathrm{C}), 127.7(2 \mathrm{C}), 127.7(2 \mathrm{C}), 127.9(8 \mathrm{C}), 133.0(\mathrm{Cq})$, $133.0(\mathrm{Cq}), 134.0(\mathrm{Cq}), 134.0(\mathrm{Cq}), 134.6(2 \mathrm{Cq}), 135.0(\mathrm{Cq}), 136.6(2 \mathrm{Cq}), 136.7(\mathrm{Cq}), 139.0(2 \mathrm{Cq}), 140.8$ (8Cq), 142.1 (2Cq), $145.2(2 \mathrm{Cq}), 145.4$ (2Cq); HRMS (APCI) calcd. for: $\mathrm{C}_{94} \mathrm{H}_{63} \mathrm{~N}_{8} \mathrm{~S}_{2}\left[\mathrm{M}+\mathrm{H}^{+}\right]$1368.4645; found: 1368.4595 .

\section{5,15-diphenyl-15,20-bis(7-(4-formyl-phenyl)-10-methyl-10H-phenothiazin-3-yl)-21,23H-porphyrin 15}

Purification by column chromatography with DCM gave: purple powder; yield 50\% (0.06 g); ${ }^{1} \mathrm{H}-\mathrm{NMR}\left(600 \mathrm{MHz}, \mathrm{CDCl}_{3}\right) \delta \mathrm{ppm}-2.76(\mathrm{~s}, 2 \mathrm{H}, \mathrm{NH}), 3.72(\mathrm{~s}, 6 \mathrm{H}), 7.11(\mathrm{~d}, 2 \mathrm{H}, J=8.0 \mathrm{~Hz}), 7.23(\mathrm{~d}, 2 \mathrm{H}, J$ $=7.1 \mathrm{~Hz}), 7.57(\mathrm{~s}, 2 \mathrm{H}), 7.60(\mathrm{~d}, 2 \mathrm{H}, J=8.5 \mathrm{~Hz}), 7.77-7.81(\mathrm{~m}, 10 \mathrm{H}), 7.96(\mathrm{~d}, 4 \mathrm{H}, J=8.0 \mathrm{~Hz}), 8.04-8.05(\mathrm{~m}$, $4 \mathrm{H}), 8.22-8.24(\mathrm{~m}, 4 \mathrm{H}), 8.86-8.93(\mathrm{~m}, 8 \mathrm{H}), 10.06(\mathrm{~s}, 2 \mathrm{H}, \mathrm{CHO}) ;{ }^{13} \mathrm{C}-\mathrm{NMR}\left(150 \mathrm{MHz}, \mathrm{CDCl}_{3}\right) \delta \mathrm{ppm} 35.8$ $(2 \mathrm{C}), 112.5(2 \mathrm{Cq}), 112.6(2 \mathrm{Cq}), 114.6(2 \mathrm{Cq}), 118.8(\mathrm{Cq}), 120.3(2 \mathrm{Cq}), 124.0(\mathrm{Cq}), 126.1(2 \mathrm{C}), 126.7(2 \mathrm{C})$, $126.7(2 \mathrm{C}), 126.9(6 \mathrm{C}), 127.0(2 \mathrm{C}), 127.2(2 \mathrm{Cq}), 127.7(2 \mathrm{C}), 130.4(4 \mathrm{C}), 130.4(2 \mathrm{C}), 133.0(2 \mathrm{C}), 134.0(2 \mathrm{C})$, $134.2(2 \mathrm{C}), 134.5(4 \mathrm{C}), 134.9(4 \mathrm{C}), 136.8(2 \mathrm{C}), 142.0(2 \mathrm{Cq}), 144.9(4 \mathrm{Cq}), 145.8(4 \mathrm{Cq}), 146.2(4 \mathrm{Cq}), 175.6$ (4Cq), 191.8 (2CHO); HRMS (APCI) calcd. for: $\mathrm{C}_{72} \mathrm{H}_{49} \mathrm{~N}_{6} \mathrm{O}_{2} \mathrm{~S}_{2}\left[\mathrm{M}+\mathrm{H}^{+}\right]$1093.3352; found: 1093.3356 .

5,10,15,20-tetrakis-[4-(3-formyl-10-methyl-10Hphenothiazin-7-yl)phenyl]-21,23H-porphyrin 17

A mixture of $0.1 \mathrm{~g}$ BrTPP, $0.23 \mathrm{~g}$ 3-formyl-10-methyl-10Hphenothiazin-7-yl boronic pinacolate, $0.025 \mathrm{~g} \mathrm{Pd}\left(\mathrm{PPh}_{3}\right)_{2} \mathrm{Cl}_{2}, 0.12 \mathrm{~g} \mathrm{~K}_{2} \mathrm{CO}_{3}, 30 \mathrm{~mL}$ DME and $15 \mathrm{~mL} \mathrm{H}_{2} \mathrm{O}$ was refluxed for $18 \mathrm{~h}$. Purification by column chromatography with DCM gave a purple powder; yield $64 \%(0.1 \mathrm{~g}) ;{ }^{1} \mathrm{H}-\mathrm{NMR}(600 \mathrm{MHz}$, $\left.\mathrm{CDCl}_{3}\right) \delta \mathrm{ppm}-2.72(\mathrm{~s}, 2 \mathrm{H}, \mathrm{NH}), 3.58(\mathrm{~s}, 12 \mathrm{H}), 6.97(\mathrm{~d}, 4 \mathrm{H}, J=8.2 \mathrm{~Hz}), 7.08(\mathrm{~d}, 4 \mathrm{H}, J=8.6 \mathrm{~Hz}), 7.18-7.20$ $(\mathrm{m}, 4 \mathrm{H}), 7.72-7.77(\mathrm{~m}, 12 \mathrm{H}), 7.95(\mathrm{~d}, 8 \mathrm{H}, J=7.9 \mathrm{~Hz}), 8.11-8.13(\mathrm{~m}, 4 \mathrm{H}), 8.28-8.31(\mathrm{~m}, 4 \mathrm{H}), 8.85-8.95$ $(\mathrm{m}, 8 \mathrm{H}), 9.87$ (s, 4H, CHO); HRMS (APCI) calcd. for: $\mathrm{C}_{100} \mathrm{H}_{67} \mathrm{~N}_{8} \mathrm{O}_{4} \mathrm{~S}_{4}\left[\mathrm{M}+\mathrm{H}^{+}\right]$1572.4196; found: 1572.3790 .

\section{5,10,15,20-tetrakis-(4'-(9H-carbazole-9yl)-[1,1'-biphenyl]-4yl)-21,23H-porphyrin 18}

A mixture of $0.1 \mathrm{~g}$ BrTPP, $0.17 \mathrm{~g}$ (4-(9H-carbazol-9-yl)phenyl)boronic acid, $0.025 \mathrm{~g} \mathrm{Pd}\left(\mathrm{PPh}_{3}\right)_{2} \mathrm{Cl}_{2}$, $0.12 \mathrm{~g} \mathrm{~K}_{2} \mathrm{CO}_{3}, 30 \mathrm{~mL} \mathrm{DME}$ and $15 \mathrm{~mL} \mathrm{H}_{2} \mathrm{O}$ was refluxed for $18 \mathrm{~h}$. Purification by column chromatography with DCM gave a purple powder; yield $65 \%(0.1 \mathrm{~g}) ;{ }^{1} \mathrm{H}-\mathrm{NMR}\left(600 \mathrm{MHz}, \mathrm{CDCl}_{3}\right) \delta \mathrm{ppm}-2.70(\mathrm{~s}, 2 \mathrm{H}$, $\mathrm{NH}), 7.38(\mathrm{t}, 6 \mathrm{H}, J=7.2 \mathrm{~Hz}, J=7.4 \mathrm{~Hz}), 7.53(\mathrm{t}, 6 \mathrm{H}, J=7.5 \mathrm{~Hz}, J=7.5 \mathrm{~Hz}), 7.62(\mathrm{~d}, 4 \mathrm{H}, J=8.1 \mathrm{~Hz}), 7.83$ $(\mathrm{d}, 8 \mathrm{H}, J=7.8 \mathrm{~Hz}), 7.91-7.94(\mathrm{~m}, 6 \mathrm{H}), 8.09-8.12(\mathrm{~m}, 10 \mathrm{H}, \mathrm{H}), 8.14(\mathrm{~d}, 8 \mathrm{H}, J=7.9 \mathrm{~Hz}), 8.24(\mathrm{~d}, 8 \mathrm{H}, J=$ $7.8 \mathrm{~Hz}), 8.38(\mathrm{~d}, 4 \mathrm{H}, J=7.5 \mathrm{~Hz}), 8.87-8.91(\mathrm{~m}, 8 \mathrm{H}), 9.03(\mathrm{~s}, 4 \mathrm{H}) ;{ }^{13} \mathrm{C}-\mathrm{NMR}\left(150 \mathrm{MHz}, \mathrm{CDCl}_{3}\right) \delta \mathrm{ppm}$ $109.9(8 \mathrm{C}), 120.1(16 \mathrm{Cq}), 120.4(8 \mathrm{C}), 123.5(8 \mathrm{C}), 125.4(4 \mathrm{Cq}), 126.0(16 \mathrm{C}), 127.6$ (8C), $128.7(16 \mathrm{C}), 130.0$ (8C), 135.2 (4Cq), 135.8 (4Cq), 135.8 (4Cq), 140.9 (12Cq); HRMS (APCI) calcd. for: $\mathrm{C}_{116} \mathrm{H}_{75} \mathrm{~N}_{8}\left[\mathrm{M}+\mathrm{H}^{+}\right]$ 1580.6142; found: 1580.6138 . 


\section{5,10,15,20-tetrakis-(4'-formyl-[1,1'-biphenyl]-4yl)-21,23H-porphyrin 19}

A mixture of $0.1 \mathrm{~g}$ BrTPP, $0.015 \mathrm{~g}$ 4-formylphenylboronic acid, $0.025 \mathrm{~g} \mathrm{Pd}\left(\mathrm{PPh}_{3}\right)_{2} \mathrm{Cl}_{2}, 0.12 \mathrm{~g} \mathrm{~K}_{2} \mathrm{CO}_{3}$, $30 \mathrm{~mL}$ DME and $15 \mathrm{~mL} \mathrm{H}_{2} \mathrm{O}$ was refluxed for $18 \mathrm{~h}$. Purification by column chromatography with DCM gave a purple powder; yield $48 \%(0.05 \mathrm{~g}) ;{ }^{1} \mathrm{H}-\mathrm{NMR}\left(600 \mathrm{MHz}, \mathrm{CDCl}_{3}\right) \delta \mathrm{ppm} 2.65(\mathrm{~s}, 2 \mathrm{H}, \mathrm{NH}), 8.09(\mathrm{~d}$, $8 \mathrm{H}, J=7.6 \mathrm{~Hz}), 8.12-8.16(\mathrm{~m}, 16 \mathrm{H}), 8.38(\mathrm{~d}, 8 \mathrm{H}, J=7.7 \mathrm{~Hz}), 8.98(\mathrm{~s}, 8 \mathrm{H}), 10.19(\mathrm{~s}, 4 \mathrm{H}, \mathrm{CHO})$; HRMS (APCI) calcd. for: $\mathrm{C}_{72} \mathrm{H}_{47} \mathrm{~N}_{4} \mathrm{O}_{4}\left[\mathrm{M}+\mathrm{H}^{+}\right]$1031.3591; found: 1031.3591.

\subsection{In Vitro Biological Assay}

The synthesized phenothiazine-bridged porphyrin-(hetero)aryl dyads with fluorescence properties selected for the biological assay which were simply labeled in this section as dyes were as follows:

5,10,15-triphenyl-20-(7-(3'-formyl-10'-methyl-10H-phenothiazine)-10-methyl-10H-phenothiazin-3-yl)21,23H-porphyrin 9

5,15-diphenyl-15,20-bis(7-(3'-formyl-10'-methyl-10'H-phenothiazin-7yl)-10-methyl-10H-phenothiazin-3-yl)21,23H-porphyrin 13

\section{5,15-diphenyl-15,20-bis(7-(4-formyl-phenyl)-10-methyl-10H-phenothiazin-3-yl)-21,23H-porphyrin 15}

The general equipment for the in vitro testing consisted of: a class II biological safety cabinet (from ESCO Micro Pte. Ltd., Singapore), an incubator with $37^{\circ} \mathrm{C}$ and $5 \% \mathrm{CO}_{2}$ parameters (Revco Ultima II, from Thermo Electron Corporation, Asheville, NC, USA), a centrifuge with swing-out rotors (32R from Hettich Lab Technology, Tuttlingen, Germany), an inverted phase microscope CKX41 (Olympus Life Sciences, Rockville, MD, USA) and a multiplate reader (Synergy2 from BioTek Company, Winooski, VT, USA).

The human ovarian tumor cell lines A2780 and A2780cis were acquired from the European Collection of Authenticated Cell Cultures (ECACC, Salisbury, UK) and the OVCAR-3 cell line was acquired from the American Type Culture Collection (ATCC, through LGC Standards GmbH, Wesel, Germany). All cell lines were grown in RPMI-1640 cell culture media. For A2780 and A2780cis cell lines the media was supplemented with $10 \%$ fetal bovine serum (FBS), while for OVCAR-3 cells $20 \%$ FBS was employed together with $0.01 \mathrm{mg} / \mathrm{mL}$ insulin from porcine pancreas (all media and supplements were from Sigma-Aldrich Chemie GmbH, Taufkirchen, Germany).

For the cytotoxicity testing, the human ovarian tumor cell lines were harvested at subconfluency and plated on 96-well microplates at a concentration of $2.5 \times 10^{4}$ cells/well in $190 \mu \mathrm{L}$ cell culture media, and after $24 \mathrm{~h}$ they were treated with the tested dyes 9, 13 and 15. Each dye was dissolved in dimethyl sulfoxide (provided by Merck, Darmstadt, Germany) and then eight serial solutions were prepared in phosphate buffered saline solution (PBS, from Sigma Aldrich). In each well, $10 \mu \mathrm{L}$ of solution was distributed ( 8 serial concentrations for each dye) and the treated cells were incubated for $24 \mathrm{~h}$. The final concentrations of the compounds in the cell media were in the range of $1.95-250.00 \mu \mathrm{M}$ for 15 , $1.88-240 \mu \mathrm{M}$ for 9 and $1.64-210 \mu \mathrm{M}$ for 13 . On every plate, wells untreated with dyes were kept as references, and wells containing cell culture media with 9, 13 and 15 solutions (without cells) were kept as color controls for each concentration. Three independent tests were performed for each dye.

The microplates containing the treated human ovarian tumor cells were subjected to cytotoxicity testing using the 3-(4,5-dimethylthiazol-2-yl)-2,5-diphenyltetrazolium bromide viability dye (MTT, from Sigma Aldrich), following a colorimetric protocol described before [29]. The optical densities of the sample supernatants, reflecting the cells' viability, were recorded, and the survival rate was calculated relative to the untreated control cell populations.

The metabolic rate of the treated human ovarian tumor cells was evaluated by the Alamar Blue test (from Life Technologies Corporation, Eugene, OR USA), as described before [30]. Briefly: the cells were seeded on 96-well plates at the same density as for MTT testing, and incubated for $24 \mathrm{~h}$ with 8 different concentrations (from 1.95 to $250 \mu \mathrm{M}$ ) of tested dyes 9, 13 and 15, respectively, in triplicates. The data provided by the fluorescence assessment were used to build a linear regression of dose-response 
relationship for each tested compound, and to quantify the results with the mathematic parameter hillslope (GraphPad Prism Software, La Jolla, CA, USA).

For the cellular uptake analysis by fluorescence microscopy, the human ovarian carcinoma cells were plated on $50 \mathrm{~mm} \mu$-dish cell culture vessels (from Ibidi GmbH, Gräfelfing, Germany), at a concentration of $10^{5}$ cells $/ \mathrm{mL}$ in cell culture media, and the dishes were treated with $50 \mu \mathrm{M} 9,13$ and 15 respectively and further kept for $24 \mathrm{~h}$. Untreated cell culture vessels were kept as references. After the treatment, the cell culture media were removed, and the vessels were washed 3 times with PBS and fixed with a $4 \%$ paraformaldehyde (from Sigma Aldrich Chemie, Taufkirchen, Germany) solution in PBS. The $\mu$-dishes were stained with $0.002 \mu \mathrm{g} / \mathrm{mL} 4^{\prime}, 6$-diamidino-2-phenylindole solution in PBS (DAPI, from Serva Electrophoresis $\mathrm{GmbH}$, Heidelberg, Germany), washed 2 times, and kept covered with PBS before the fluorescence microscope evaluation.

\subsection{Fluorescence Imaging of Human Ovarian Tumor Cell Lines}

The fluorescence images of A2780cis cells treated with 13 were collected with an inverted Axio Observer Z1 microscope (from Carl Zeiss), using a Compact Light Source HXP 120 C mercury lamp. Briefly, the light was reflected by a dichroic mirror using $\mathrm{G} 365$ excitation filter (i.e., filter set 49 from Carl Zeiss) in order to visualize the cell nuclei, and an excitation filter BP 470/40 (i.e., filter set 38 from Carl Zeiss) was employed to image the localization of dye 13. The bright-field and fluorescence images were captured using a 63x iris oil immersion objective and a Zeiss AxioCam MRm monochrome microscope camera and then processed using the ZEN software.

Fluorescence lifetime imaging microscopy under two-photons excitation (TPE-FLIM) images on the A2780 cells post $24 \mathrm{~h}$ treatment were performed using a MicroTime 200 time-resolved confocal fluorescence microscope system (IX 71, Olympus) and coupled to a Mira 900 Titanium:Sapphire tunable femtosecond laser (from Coherent). The incubated A2780 cells were imaged under the microscope at $800 \mathrm{~nm}$ laser beam using up to $25 \mathrm{~mW}$ laser power, using the same system configuration described previously [42]. The signal was subsequently collected using a Plan N 40x objective with numerical aperture (NA) of 0.65 and spectrally filtered by a FF01-750 SP emission filter (Semrock, USA). The TPE-FLIM images were acquired and analyzed by the SymPhoTime software provided by PicoQuant. Bright-field images of the A2780 cells scanned through TPE-FLIM were collected on the same microscope, using an Olympus IX-2LW UCD condenser and an Olympus CAM-XC30 digital camera.

\section{Conclusions}

The family of meso-phenothiazinyl-phenyl-porphyrin MPP dyes was substantially extended by synthesizing the new halogen-MPP of $\mathrm{AB}_{3}$-type (containing one peripheral halogenophenothiazine unit) and the trans $-\mathrm{A}_{2} \mathrm{~B}_{2}$ type (two peripheral halogenophenothiazine units) further employed, on the one hand, as ligands in new metal-complexes, and on the other hand, as scaffolds for peripheral modification by Suzuki-Miyaura cross coupling with various (hetero)arylboronic acid derivatives. The cross-coupling methodology applied afforded a series of meso-phenothiazine-bridged porphyrin-(hetero)aryl dyads in good yields (40-70\%). The examination of the UV-Vis optical properties of the newly synthesized compounds emphasized the absorption/emission properties of the porphyrin chromophore slightly modulated by the substitution pattern. In comparison with para-phenylene, substitution of phenothiazine in positions 3,7 gave a less effective bridge for the extension of the $\pi$-electron system of the novel porphyrine-(hetero)aryl dyads. Increasing the size of the peripheral substituents did not improved the absorption characteristics of MPP dyes in the visible range, but it emphasized attractive NIR fluorophore properties for the symmetrical trans $\mathrm{A}_{2} \mathrm{~B}_{2}$ type phenothiazine-bridged porphyrin-phenothiazine dyad 13.

According to cell viability colorimetric assays (MTT and Alamar Blue), the phenothiazine-bridged porphyrin-phenothiazine dyads 9,13 and 15 exhibit a moderate cytotoxicity on ovarian tumor cell lines in vitro. 
The green emissive dye 13 can be successfully employed for living human ovarian tumor cell staining, at $50 \mu \mathrm{M}$ presenting a good cell internalization without affecting the cell viability and having the capability to stain the cells' nuclei. Visualization of the stained cells can be performed both by fluorescence imaging and TPE-FLIM imaging.

Supplementary Materials: Supplementary materials can be found at http://www.mdpi.com/1422-0067/21/9/3178/ s1.

Author Contributions: Conceptualization, E.G. and L.G.; methodology, L.G., E.G. and E.M.; validation L.G., E.G. and E.M.; formal analysis E.G. and E.M.; investigation, E.M.; resources, L.S.-D.; data curation, C.C.; writing-original draft preparation, C.C.; writing—review and editing, C.C.; visualization, L.G.; supervision, L.S.-D.; project administration, L.G.; funding acquisition; biological assay, M.P.-S. and E.F.-F.; biological activity study design, P.A.-C.; fluorescence imaging, M.F. All authors have read and agreed to the published version of the manuscript.

Funding: This work was supported by a grant of Romanian Ministry of Research and Innovation, CNCS-UEFISCDI, project number PN-III-P4-ID-PCCF-2016-0142, within PNCDI III, and The APC was funded by PN-III-P4-ID-PCCF-2016-0142.

Conflicts of Interest: The authors declare no conflict of interest. The funders had no role in the design of the study; in the collection, analyses, or interpretation of data; in the writing of the manuscript, or in the decision to publish the results.

\section{Abbreviations}

MPP meso-phenothiazinyl-phenyl porphyrin

BrMPP meso-bromophenothiazinyl-phenyl porphyrin

BrTPP meso-tetrakis(4-bromo-phenyl)porphyrin

\section{References}

1. Qiu, X.; Lu, R.; Zhou, H.; Zhang, X.; Xu, T.; Liu, X.; Zhao, Y. Synthesis of phenothiazine-functionalized porphyrins with high fluorescent quantum yields. Tetrahedron Lett. 2008, 49, 7446-7449. [CrossRef]

2. Prakash, K.; Alsaleh, A.Z.; Rathi, P.; Sharma, A.; Sankar, M.; D'Souza, F. Synthesis, Spectral, Electrochemical and Photovoltaic Studies of $\mathrm{A}_{3} \mathrm{~B}$ Porphyrinic Dyes having Peripheral Donors. ChemPhysChem 2019, 20, 2627-2634. [CrossRef] [PubMed]

3. Kumar, R.; Sudhakar, V.; Prakash, K.; Krishnamoorthy, K.; Sankar, M. Tuning the Photovoltaic Performance of DSSCs by Appending Various Donor Groups on trans-Dimesityl Porphyrin Backbone. ACS Appl. Energy Mater. 2018, 1, 2793-2801. [CrossRef]

4. Zeng, K.; Tang, W.; Li, C.; Chen, Y.; Zhao, S.; Liu, Q.; Xie, Y. Systematic optimization of the substituents on the phenothiazine donor of doubly strapped porphyrin sensitizers: An efficiency over $11 \%$ unassisted by any cosensitizer or coadsorbent. J. Mater. Chem. A 2019, 7, 20854-20860. [CrossRef]

5. Song, H.; Li, X.; Ågren, H.; Xie, Y. Branched and linear alkoxy chains-wrapped push-pull porphyrins for developing efficient dye-sensitized solar cells. Dyes Pigments 2017, 137, 421-429. [CrossRef]

6. Abu-Melha, S. Efficient synthesis of meso-substituted porphyrins andmolecular docking as potential new antioxidant andcytotoxicity agents. Arch. Pharm. Chem. Life Sci. 2019, 352, e1800221. [CrossRef]

7. Gal, E.; Brem, B.; Pereţeanu, I.; Găină, L.; Lovasz, T.; Perde-Schrepler, M.; Silaghi-Dumitrescu, L.; Cristea, C.; Silaghi-Dumitrescu, L. Novel meso-phenothiazinylporphyrin dyes: Synthesis, optical, electrochemical properties and PDT assay. Dyes Pigments 2013, 99, 144-153. [CrossRef]

8. Brem, B.; Gal, E.; Gaina, L.; Cristea, C.; Gabudean, A.M.; Astilean, S.; Silaghi-Dumitrescu, L. Metallo complexes of meso-phenothiazinylporphyrins: Synthesis, linear and nonlinear optical properties. Dyes Pigments 2015, 123, 386-395. [CrossRef]

9. Miyaura, N.; Yamada, K.; Suzuki, A. A new stereospecific cross-coupling by the palladium catalyzed reaction of 1-alkenylboranes with 1-alkenyl or 1-alkynylhalides. Tetrahedron Lett. 1979, 20, 3437-3440. [CrossRef]

10. Suzuki, A. Cross coupling reactions via organoboranes. J. Organomet. Chem. 2002, 653, 83-90. [CrossRef]

11. Suzuki, A. Organoboranes in organic synthesis including Suzuki coupling reaction. Heterocycles 2010, 80, 15-43. [CrossRef] 


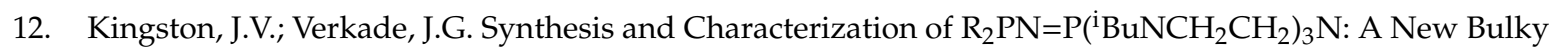
Electron-Rich Phosphine for Efficient Pd-Assisted Suzuki-Miyaura Cross-Coupling Reactions. J. Org. Chem. 2007, 72, 2816-2822. [CrossRef]

13. Dolliver, D.; Bhattarai, B.T.; Pandey, A.; Lanier, M.L.; Bordelon, A.S.; Adhikari, S.; Dinser, J.A.; Flowers, P.F.; Wills, V.S.; Schneider, C.L.; et al. Stereospecific Suzuki, Sonogashira, and Negishi Coupling Reactions of N-Alkoxyimidoyl Iodides and Bromides. J. Org. Chem. 2013, 78, 3676-3687. [CrossRef] [PubMed]

14. Saito, B.; Fu, G.C. Alkyl-Alkyl Suzuki Cross-Couplings of Unactivated Secondary Alkyl Halides at Room Temperature. J. Am. Chem. Soc. 2007, 129, 9602-9603. [CrossRef] [PubMed]

15. Baillie, C.; Zhang, L.; Xiao, J. Ferrocenyl Monophosphine Ligands: Synthesis and Applications in the Suzuki-Miyaura Coupling of Aryl Chlorides. J. Org. Chem. 2004, 69, 7779-7782. [CrossRef]

16. Lipshutz, B.H.; Petersen, T.B.; Abela, A.R. Room-Temperature Suzuki-Miyaura Couplings in Water Facilitated by Nonionic Amphiphiles. Org. Lett. 2008, 10, 1333-1336. [CrossRef]

17. Krämer, C.S.; Zimmermann, T.J.; Sailer, M.; Müller, T.J.J. Syntheses of Phenothiazinylboronic Acid Derivatives-Suitable Starting Points for the Construction of Redox Active Materials. Synthesis 2002, 9, 1163-1170. [CrossRef]

18. Onoabedje, E.A.; Uchechukwu, C.O.; Knight, D.W.; Sarkar, A. Fuctionalization of Linear and Angular Phenothiazine and Phenoxazine Ring Systems via Pd(0)/XPhos Mediated Suzuki-Miyaura Cross-coupling Reactions. J. Heterocyclic Chem. 2016, 53, 1787-1794. [CrossRef]

19. Grisorio, R.; Roose, B.; Colella, S.; Listorti, A.; Suranna, G.P.; Abate, A. Molecular Tailoring of Phenothiazine-Based Hole-Transporting Materials for High- Performing Perovskite Solar Cells. ACS Energy Lett. 2017, 2, 1029-1034. [CrossRef]

20. Liu, X.; Tan, X.; Chen, Q.; Shan, H.; Liu, C.; Xu, J.; Chen, Z.K.; Huang, W.; Xu, Z.X. Facile synthesis of a dopant-free hole transporting material with a phenothiazine core for planar perovskite solar cells. RSC Adv. 2017, 7, 53604-53610. [CrossRef]

21. Chao, P.; Gu, R.; Ma, X.; Wang, T.; Zhaod, Y. Thiophene-substituted phenothiazine-based photosensitisers for radical and cationic photopolymerization reactions under visible laser beams (405 and $455 \mathrm{~nm}$ ). Polym. Chem. 2016, 7, 5147-5156. [CrossRef]

22. Vaz, B.; Alvarez, R.; Nieto, M.; Paniello, A.I.; de Lera, A.R. Suzuki cross-coupling of meso-dibromoporphyrins for the synthesis of functionalized A2B2 porphyrins. Tetrahedron Lett. 2001, 42, 7409-7412. [CrossRef]

23. Aratani, N.; Osuka, A. Synthesis of meso-meso Linked Hybrid Porphyrin Arrays by Pd-Catalyzed Cross-Coupling Reaction. Org. Lett. 2001, 3, 4213-4216. [CrossRef] [PubMed]

24. Bakar, M.A.; Sergeeva, N.N.; Juillard, T.; Senge, M.O. Synthesis of Ferrocenyl Porphyrins via Suzuki Coupling and Their Photophysical Properties. Organometallics 2011, 30, 3225-3228. [CrossRef]

25. Diev, V.V.; Schlenker, C.W.; Hanson, K.; Zhong, Q.; Zimmerman, J.D.; Forrest, S.R.; Thompson, M.E. Porphyrins Fused with Unactivated Polycyclic Aromatic Hydrocarbons. J. Org. Chem. 2012, 77, 143-159. [CrossRef] [PubMed]

26. Kramer, C.S.; Zeitler, K.; Mu1ller, T.J.J. Synthesis of Functionalized Ethynylphenothiazine Fluorophores. Org. Lett. 2000, 2, 3723-3726. [CrossRef]

27. Adler, A.D.; Longo, F.R.; Kampas, F.; Kim, J. On the preparation of metalloporphyrins. J. Inorg. Nucl. Chem. 1970, 32, 2443-2445. [CrossRef]

28. Gong, J.; Han, J.; Liu, Q.; Ren, X.; Wei, P.; Yang, L.; Zhang, Y.; Liu, J.; Dong, Y.Q.; Wang, Y.; et al. An ideal platform of light-emitting materials from phenothiazine: Facile preparation, tunable red/NIR fluorescence, bent geometry-promoted AIE behaviour and selective lipid-droplet (LD) tracking ability. J. Mater. Chem. C 2019, 7, 4185-4190. [CrossRef]

29. Boșca, B.A.; Ilea, A.; Sorițău, O.; Tatomir, C.; Miklášová, N.; Pârvu, A.E.; Mihu, C.M.; Melincovici, C.S.; Fischer-Fodor, E. Modulatory effect of curcumin analogs on the activation of metalloproteinases in human periodontal stem cells. Eur. J. Oral Sci. 2019, 127, 304-312. [CrossRef]

30. Perde-Schrepler, M.; Florea, A.; Brie, I.; Virag, P.; Fischer-Fodor, E.; Vâlcan, A.; Gurzău, E.; Lisencu, C.; Maniu, A. Size-Dependent Cytotoxicity and Genotoxicity of Silver Nanoparticles in Cochlear Cells In Vitro. J. Nanomater. 2019, 2019, 6090259. [CrossRef]

31. Shashkova, S.; Leake, M.C. Single-molecule fluorescence microscopy review: Shedding new light on old problems. Biosci. Rep. 2017, 37, 37. [CrossRef] [PubMed] 
32. Yu, Q.; Chen, S.; Han, C.; Guo, H.; Yang, F. High solid fluorescence of novel tetraphenylethene-porphyrin. J. Lumin. 2020, 220, 117017. [CrossRef]

33. Khadria, A.; Fleischhauer, J.; Boczarow, I.; Wilkinson, J.D.; Kohl, M.; Anderson, H.L. Porphyrin Dyes for Nonlinear Optical Imaging of Live Cells. iScience 2018, 4, 153-163. [CrossRef] [PubMed]

34. Zhu, M.; Su, C.; Xing, P.; Zhou, Y.; Gong, L.; Zhang, J.; Du, H.; Bian, Y.; Jiang, J. An AceDAN-porphyrin(Zn) dyad for fluorescence imaging and photodynamic therapy via two-photon excited FRET. Inorg. Chem. Front. 2018, 5, 3061-3066. [CrossRef]

35. Zhu, M.; Zhang, J.; Zhou, Y.; Xing, P.; Gong, L.; Su, C.; Qi, D.; Du, H.; Bian, Y.; Jiang, J. Two-Photon Excited FRET Dyads for Lysosome-Targeted Imaging and Photodynamic Therapy. Inorg. Chem. 2018, 57, 11537-11542. [CrossRef]

36. Lia, S.; Zhanga, Y.; Hea, X.-W.; Li, W.-Y.; Zhangab, Y.-K. Multifunctional mesoporous silica nanoplatform based on silicon nanoparticles for targeted two-photon-excited fluorescence imaging-guided chemo/photodynamic synergetic therapy in vitro. Talanta 2020, 209, 120552. [CrossRef]

37. Valanciunaite, J.; Klymchenko, A.S.; Skripka, A.; Richert, L.; Steponkiene, S.; Streckyte, G.; Mély, Y.; Rotomskis, R. A non-covalent complex of quantum dots and chlorin e 6: Efficient energy transfer and remarkable stability in living cells revealed by FLIM. RSC Adv. 2014, 4, 52270-52278. [CrossRef]

38. Prashanth, K.P.; Maiya, B.G. Aluminium(III) porphyrin based dimers and trimers: Synthesis, spectroscopy and photochemistry. New J. Chem. 2003, 27, 619-625. [CrossRef]

39. Mao, M.; Zhang, X.; Cao, L.; Tong, Y.; Wu, G. Design of Bodipy based organic dyes for high-efficient dye-sensitized solar cells employing double electron acceptor. Dyes Pigments 2015, 117, 28-36. [CrossRef]

40. Wang, P.; Fan, S.; Liang, J.; Ying, L.; You, J.; Wang, S.; Li, X. Carbazole-diphenylimidazole based bipolar material and its application in blue, green and red single layer OLEDs by solution processing. Dyes Pigments 2017, 142, 175-182. [CrossRef]

41. Kurniawan, F.; Miura, Y.; Kartasasmita, R.E.; Mutalib, A.; Yoshioka, N.; Tjahjono, D.H. In Silico Study, Synthesis, and Cytotoxic Activities of Porphyrin Derivatives. Pharmaceuticals 2018, 11, 8. [CrossRef] [PubMed]

42. Suarasan, S.; Craciun, A.-M.; Licarete, E.; Focsan, M.; Magyari, K.; Astilean, S. Intracellular Dynamic Disentangling of Doxorubicin Release from Luminescent Nanogold Carriers by Fluorescence Lifetime Imaging Microscopy (FLIM) under Two-Photon Excitation. ACS Appl. Mater. Interfaces 2019, 11, 7812-7822. [CrossRef] [PubMed]

(C) 2020 by the authors. Licensee MDPI, Basel, Switzerland. This article is an open access article distributed under the terms and conditions of the Creative Commons Attribution (CC BY) license (http://creativecommons.org/licenses/by/4.0/). 